\title{
Use of Road Stabilizers in Sensitive Environments
}

\author{
P McKendry
}

\begin{abstract}
Road infrastructure is key for any developing country to enable its expansion such as those in Africa. Natural road construction materials can become depleted and increasing traffic loads produce higher maintenance requirements, leading to research to develop additives that can be used to enhance the engineering properties of available pavement soils. Providing all weather roads for large vehicles in rural areas, such as Northern Namibia, are often based only on the available soils, involving compaction and use of stabilizers, is required to both provide a suitable load bearing road surface and maintain the road network. The region is also environmentally sensitive to any potentially adverse impacts of chemicals that may be released into the environment during construction or as breakdown products. A number of road stabilizer products are available and the choice of stabilizer must take into account both its specific properties and the sensitivity of the environment where it is to be used to any environmental impacts. The main stabilizer types are cementitious, bituminous and chemical, with the latter broken down in a range of materials including synthetic polymer binders, organic and ionic compounds, salts, enzymatic products and combinations thereof. Twenty available stabilizer products were considered in terms of their environmental properties and assessed against the published literature and the general findings reported in terms of the overall ranking of the environmental impact of stabilizer types.
\end{abstract}

Keywords: environmental impact, roads, sensitivity, stabilizers

\section{INTRODUCTION}

Provision of a secure road network in developing countries is key to enable the cost effective and safe movement of goods and people. While the use of concrete and tarmac to surface road networks is common in developed countries this is usually not possible in developing countries, except in cities.

As development continues internationally, increasing kilometres of roads are being constructed and multitudes of roads are being rehabilitated and maintained annually. Natural road construction materials that were used historically are being depleted and traffic loads continue to increase. As a result, research is ongoing to develop additives that can be used to enhance the engineering properties of available pavement soils.

Roads in rural areas therefore are based on the soils available in the region and to make them usable for large vehicles in all weathers the soil must be compacted and stabilised to provide a cohesive, load bearing, road surface. This is achieved by a combination of civil engineering measures to form the road surface and use of chemical additives, known as soil stabilizers, added to the soil to enable a compacted road surface to be formed.

Revised Manuscript Received on June 13, 2020.

* Correspondence Author

P McKendry*, Technical Director, SLR Consulting (UK) Ltd

(C) The Authors. Published by Blue Eyes Intelligence Engineering and Sciences Publication (BEIESP). This is an open access article under the CC BY-NC-ND license (http://creativecommons.org/licenses/by-nc-nd/4.0/)
The choice of which stabilizer to apply must take into account both the specific properties of the stabilizer and the sensitivity of the environment where the stabilizer is to be used, to ensure any potential adverse environmental impacts are avoided wherever possible or at least minimised.

One such location where road stabilizers are required to provide and maintain the road network is Namibia, south west Africa. In Namibia road construction materials have always been scarce in the northern regions, where most development of new roads is focussed.

In recent years numerous vendors of road stabilizing agents have introduced a variety of proprietary products to both the Roads Authority and private developers throughout Namibia. These products present opportunities to address a number of challenges relating to both the provision of new roads and maintaining existing roads. However, before such products are submitted for trials, it would be helpful to ascertain what the potential environmental and health related impacts of such products could be and how to implement their use in a responsible manner.

Recognizing the need for investigating alternative methods that would enable cost effective construction of new roads, especially in rural areas the Roads Authority of Namibia commissioned SLR Environmental Consulting (Namibia) (Pty) Ltd, Colin Christian \& Associates and specialist inputs on the chemistry of stabilizers from SLR UK, to ascertain the potential environmental and health related impacts of such products and how to apply their use in a responsible manner. This paper reports the outcome of the exercise.

\section{SENSITIVE ENVIRONMENTS}

The definition of a sensitive environment will depend on a number of factors. One such definition (Ref 1) states that: If a habitat or species is very adversely affected by an external factor arising from human activities or natural events (killed/destroyed) and is expected to recover over a very long period of time, (10-20 years) then it would be considered to be highly sensitive.

Sensitivity is dependent on the tolerance of a species or habitat to damage from an external factor, and the time taken for its subsequent recovery from damage sustained as a result of an external factor. Assessments of tolerance takes rarity into account, as the rarer a habitat is the more an external factor is likely to damage a significant proportion of the habitat and therefore it will have a lower tolerance rating.

Published By: Blue Eyes Intelligence Engineering \& Sciences Publication (C) Copyright: All rights reserved.

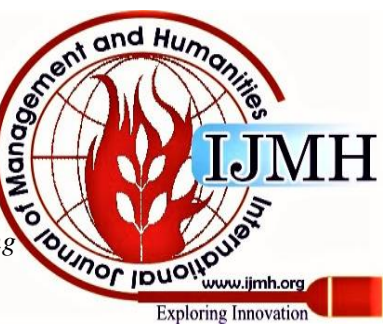




\section{Use of Road Stabilizers in Sensitive Environments}

On this basis the northern region of Namibia is considered to comprise a number of environmentally sensitive areas and determining the environmental impacts of any chemical compounds in such environments raises several challenges:

- chemical composition of the stabilizers must be known, including whether there are any impurities (unintended contents) and what the breakdown products are in the environment. The latter requires that one also needs to understand the chemical interactions with the soil;

- determination of what compounds and breakdown products should be looked for;

- ascertain what aspects of the receiving environment and what organisms may be affected;

- organisms may be affected in many ways that are non-lethal but can still pose a threat to a population. Persistent toxins i.e. those that don't break down rapidly, often accumulate in the food chain and may impact organisms at the end of the food chain. Such impacts may not kill organisms but may affect breeding success, or harm prey species, microorganisms, aquatic plants or any other living component of an ecosystem.

Attention has been drawn to aquatic ecosystems, as aquatic life is often sensitive to toxins and water can transport contaminants long distances. All areas producing runoff to surface water bodies should therefore be regarded as sensitive.

In summary:

- selection of road stabilizers must take into account whether they could pose any risk to aquatic ecosystems, and

- where there is a lack of knowledge about the chemical or physical impacts of stabilizers, or their breakdown products the Precautionary Principle should be applied. In practice this requires avoidance of situations where harmful substances could access water bodies, including both perennial and ephemeral water bodies. The following habitats could be at risk, even if they are seasonally inundated or remain dry for years at a time: -

○ perennial rivers;

○ floodplains;

- lakes, pans, lagoons, backwaters etc;

- reedbeds, papyrus, and hygrophilous (water loving) grasses;

- omurambas and oshanas (dry watercourses);

- salt pans;

○ springs and wetlands fed by groundwater;

o karst areas, whether known to have cave lake fauna or not (normally karst areas will not require stabilizers, as they can provide conventional road building materials);

o areas close to shallow wells (omifima), or where shallow groundwater exists that may be utilised by people and livestock.
- terrestrial plants may be less sensitive to low concentrations of chemicals that may be toxic to other organisms but in the context of Namibia:

○ 30 species of trees are known to be endemic to Namibia; and

- 87 species are protected under various pieces of legislation or have conservation status in some form.

Figures 1- 6 illustrate both the types of underlying geology and the range of environmental settings found in Namibia.

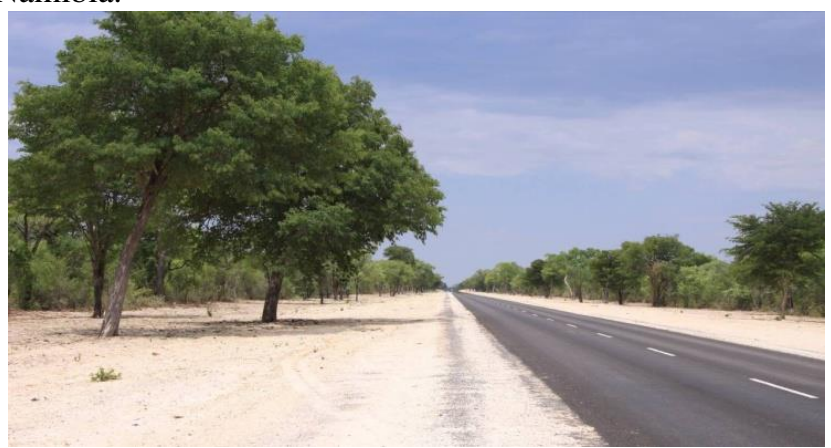

Figure 1: Road upgrade Ohangwena Region

The road upgrade in Figure 1 required use of scarce calcrete and silcrete for layer works

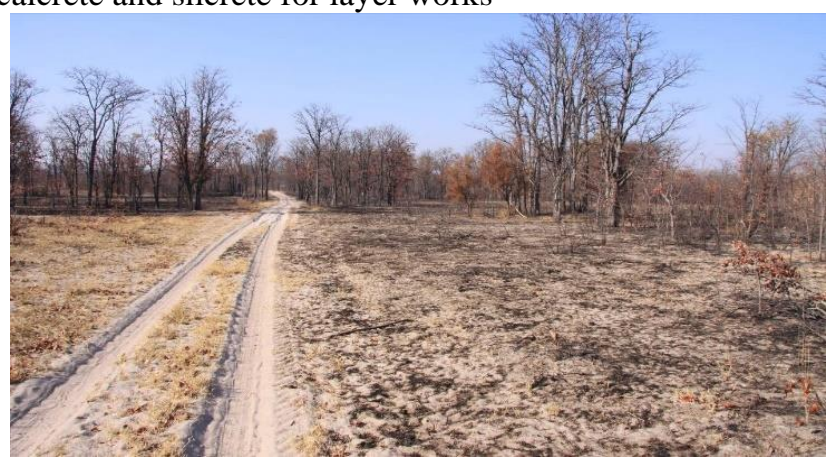

Figure 2: Sand track Caprivi region

Materials for road making in sandy areas are scarce, hence the use of stabilizers would assist the development of road infrastructure in the region.

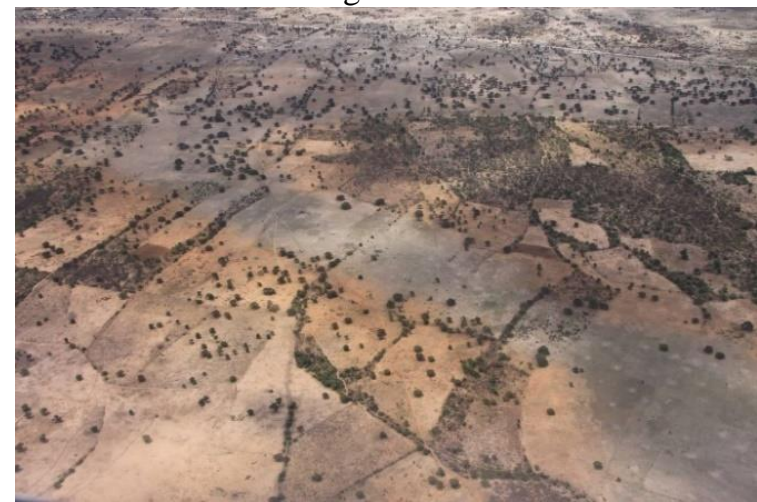

Figure 3: northern Kavango

The area of northern Kavango has sandy soils and no outcrops of rock or materials such as calcrete suitable for road making.

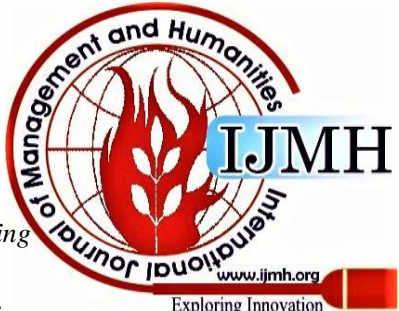




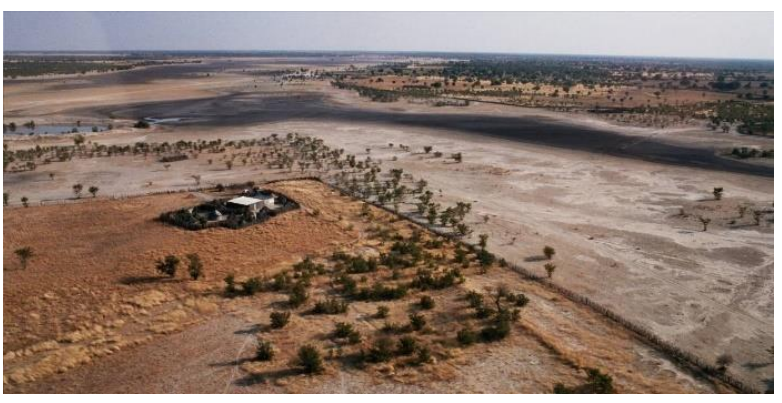

Figure 4: Ephemeral watercourse

Ephemeral watercourses in the western part of the Cuvelai system would be influenced by any releases from road stabilizers.

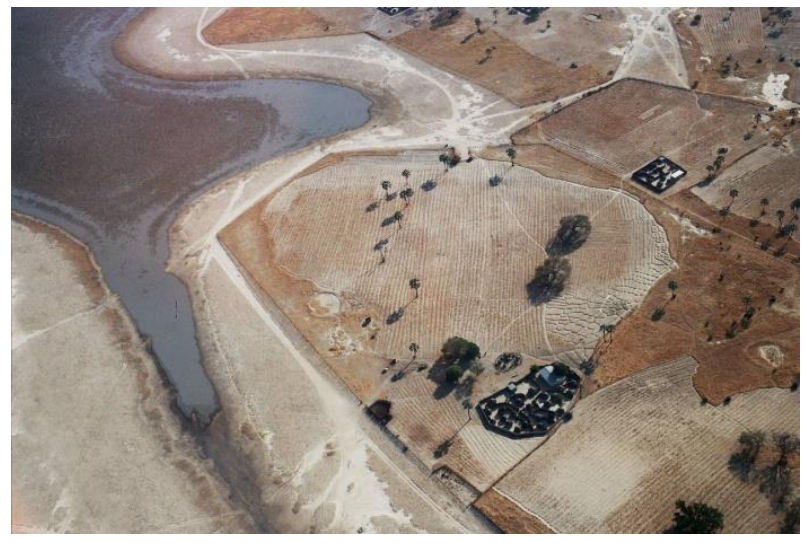

Figure 5: Agriculture and fishing

Dense rural settlements in the Cuvelai system are highly reliant on suitable agricultural soils and fish provided by the floodwaters; hence the environmental potential impact of stabilizer materials could be significant.

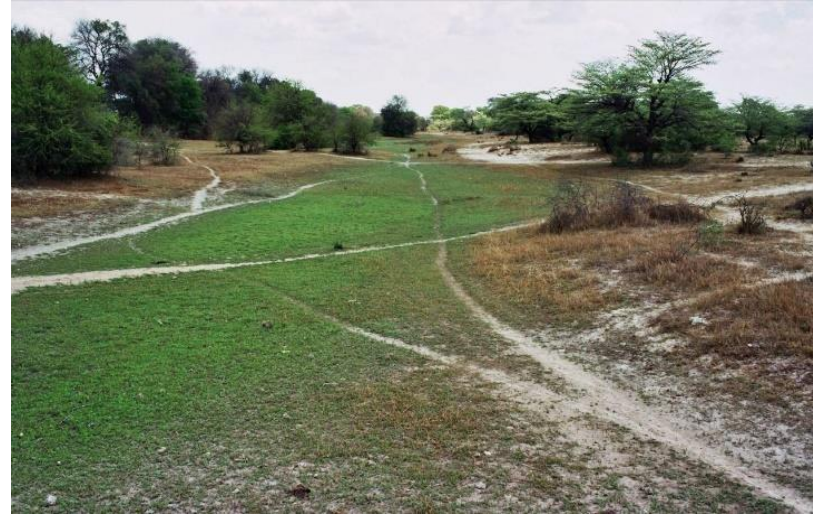

Figure 6: Ephemeral watercourse or "omuramba"

Figure 6 shows an ephemeral watercourse, or "omuramba", in Kavango that could be adversely impacted by the incorrect or inappropriate use of road stabilizers.

\section{STABILIZER PRODUCTS}

In order to provide a proper background to the use of stabilizers in road construction the following definitions are used:

- Soil: any combination of rock (crushed or uncrushed), gravel, sand, silt and clay;

- Stabilisation: treatment of soils by chemical or other means, in order to improve their engineering properties;
- Stabilising agent (stabilizer): chemical added to a soil to improve the engineering properties of the soil.

- Modification: improvement in properties obtained when a material is stabilized and there is not necessarily a development of a compressive or tensile strength. Modification is usually employed to reduce the Plasticity Index (PI) and to increase the California Bearing Ratio (CBR). The term

"Modified Material" is also used.

It is further noted that cement or lime stabilization is a recognized engineering practise used extensively in Namibia and internationally. The environmental impacts of these methods are not considered. The study focused solely on the environmental impacts of patented/proprietary stabilizers.

Good quality road construction material is often unavailable in parts of Namibia. The transport costs of importing suitable materials have supported the development of stabilisation techniques able to utilise locally available resources. Often the required strengths can be obtained by altering the characteristics of locally available, sub-standard materials and stabilization is one such technique.

The objective of applying stabilizers is to bind the individual aggregate particles together, to increase strength and/or make the material more water-resistant. The addition of small amounts of stabilising agents, at a relatively low cost, can increase significantly the strength and water resistance characteristics of road construction materials.

Polymer stabilizers are of the order three times more expensive than Portland cement. Typical applications range between 1 to $2 \%$ (up to $6 \%$ ) of the mass of the material being treated, with the main deciding factor usually being the cost of the stabilizers.

Commonly, utilization of polymer stabilizers is not cost effective for smaller projects, or projects that have sufficient suitable quality, road construction materials available. Another important cost factor is that specialized equipment is often required.

Conventional lime or cement stabilization is generally more cost effective, except in cases where the availability of construction material is very low.

It was expected that the use of stabilizers in Namibia by the Roads Authority would be for the following scenarios:

- rehabilitation of existing roads by recycling pavement layers and introducing stabilizing agents as part of major construction projects.

- new road construction projects in areas with insufficient road construction materials, where the requirement is to upgrade the engineering properties of in-situ, or substandard borrow materials, by addition of stabilising agents.

- ongoing maintenance requirements, where the base course of short sections of road are repaired.

Stabilizing agents are normally categorized as cementitious, bituminous, or chemical and are normally categorized according to its major constituent.

Published By: Blue Eyes Intelligence Engineering \& Sciences Publication (C) Copyright: All rights reserved.

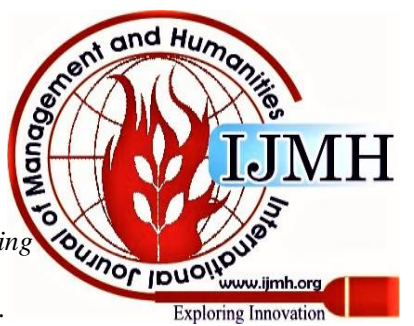




\section{Use of Road Stabilizers in Sensitive Environments}

Further subdivision of stabilizer categories used in this document are derived from AustRoads (Austroads Stabilising Binders, 2009).

Table 1 summarizes the main types of stabilizer and properties.

Cementitious: cement, lime, or a combination of either with milled granulated blast furnace slag (MGBS) or fly ash (FA):

- Lime (slaked or unslaked);

- Cement;

- Pozzolanic materials;

- MGBS, iron and steel slags;

- Fly ash, coal fired power stations

Bituminous:

- Bitumen emulsion;

- Foamed bitumen;

- Bitumen with secondary binders, such as mineral filler, rock dust and fly ash

\section{Chemical:}

- Synthetic polymer binders;

○ Insoluble dry powdered synthetic polymer (IDPSP)

○ Synthetic soluble polymers

- Organic;

- Ionic compounds;

- Salts;

- Enzymatic (not included in Austroads 2009) (Ref. 2)

Table 1: Stabilizer types and properties

\begin{tabular}{|c|c|c|c|}
\hline No & \multicolumn{2}{|c|}{ TYPE } & DESCRIPTION \\
\hline 1 & \multirow{2}{*}{$\begin{array}{l}\text { Synthetic } \\
\text { Polymer } \\
\text { Binders }\end{array}$} & & \\
\hline 1.1 & & $\begin{array}{l}\text { Insoluble } \\
\text { Dry } \\
\text { Powdered } \\
\text { Synthetic } \\
\text { Polymer } \\
\text { (IDPSP) }\end{array}$ & $\begin{array}{l}\text { Water insoluble dry powder } \\
\text { thermally bound to a fine carrier } \\
\text { such as fly ash. Not to be confused } \\
\text { with dust suppressants. Fine } \\
\text { powdered product mixed with } \\
\text { hydrated lime, flocculates and } \\
\text { coats clay particles within the } \\
\text { pavement material. Fly ash } \\
\text { encapsulated by polymer is } \\
\text { effectively inert and does not react } \\
\text { in the stabilisation process. Its } \\
\text { function is to facilitate distribution } \\
\text { of polymer in the pavement } \\
\text { material. IDPSP is used as powder } \\
\text { and remains in a powder form } \\
\text { during the pavement material } \\
\text { mixing. Most insoluble synthetic } \\
\text { polymers preserve the dry strength } \\
\text { of pavement materials by creating a } \\
\text { hydrophobic soil matrix, reducing } \\
\text { permeability and minimising water } \\
\text { absorption into the clayey fines. } \\
\text { Three blends are commercially } \\
\text { available and spread at a rate of } 1 \% \\
\text { to } 2 \% \text { by dry mass of pavement } \\
\text { material. The synthetic polymer } \\
\text { thermally bonded to a fine powder } \\
\text { carrier (i.e. fly ash): } \\
\text { blend } 2: 1 \text { synthetic } \\
\text { polymer-coated fly ash/ } \\
\text { hydrated lime for } \\
\text { medium plasticity } \\
\text { blend of } 1: 1 \text { synthetic } \\
\text { holymer-coated fly ash/ } \\
\text { onded lime for higher }\end{array}$ \\
\hline
\end{tabular}

Published By: Blue Eyes Intelligence Engineering \& Sciences Publication (C) Copyright: All rights reserved. plasticity

\begin{tabular}{|c|c|c|c|}
\hline & & & plasticity \\
\hline 1.2 & & $\begin{array}{l}\text { Synthetic } \\
\text { Soluble } \\
\text { Polymers }\end{array}$ & $\begin{array}{l}\text { Added to the compaction water to } \\
\text { form a polymer chain which is an } \\
\text { acrylimide or urethane copolymer. } \\
\text { Products encapsulate soil particles } \\
\text { with a thin film of polymer and, } \\
\text { upon drying, create bonding and } \\
\text { water insolubility is achieved. }\end{array}$ \\
\hline 2 & Organic & & $\begin{array}{l}\text { By-product of the timber pulping } \\
\text { industry (sulphonated lignin, tall } \\
\text { oil pitch) or citrus industry } \\
\text { (sulphonated di-limonene). Lignin } \\
\text { sulphonates (sodium, calcium and } \\
\text { ammonium lignin sulphonates) and } \\
\text { di-limonene are by-products of the } \\
\text { 'Kraft' pulping. Tall oil pitch } \\
\text { usually converted into a water- } \\
\text { based emulsion to facilitate } \\
\text { handling and application. Tall oil } \\
\text { pitch adheres the fine particles of } \\
\text { the soil or pavement material; the } \\
\text { glued matrix interlocks the larger } \\
\text { aggregates. Hydrophobic property } \\
\text { of tall oil pitch reduces water } \\
\text { permeability of soils and pavement } \\
\text { materials. Particle size distribution } \\
\text { and plasticity influence the } \\
\text { selection of material to be } \\
\text { stabilised with organic binders. } \\
\text { High plastic materials, with tall oil } \\
\text { pitch, have demonstrated improved } \\
\text { cohesion and neutralised clay } \\
\text { reactivity. }\end{array}$ \\
\hline 3 & Ionic & & $\begin{array}{l}\text { Mainly from sulphonated } \\
\text { petroleum products and highly } \\
\text { ionic. Electrochemical dust } \\
\text { suppressants work by expelling } \\
\text { adsorbed water from the soil that } \\
\text { decreases air voids and increases } \\
\text { compaction. }\end{array}$ \\
\hline 4 & Salts & & $\begin{array}{l}\text { Largely waste products from the } \\
\text { salt production or naturally- } \\
\text { occurring in salt lakes. Magnesium } \\
\text { chloride forms a large component } \\
\text { of sea water. Salts suppress dust by } \\
\text { attracting and trapping moisture } \\
\text { from the air, keeping the road } \\
\text { surface moist. When the } \\
\text { atmospheric moisture falls below a } \\
\text { certain level, these chemicals lose } \\
\text { their effectiveness. Hygroscopic } \\
\text { chlorides (sodium chloride) cease } \\
\text { to function at below } 70 \% \text { relative } \\
\text { humidity and deliquescent } \\
\text { chlorides (calcium chloride and } \\
\text { magnesium chloride) cease to } \\
\text { function below } 30 \text { to } 40 \% \text { relative } \\
\text { humidity, depending upon the } \\
\text { ambient temperature. These types } \\
\text { of binders are not suitable for use } \\
\text { where a bituminous spray seal or } \\
\text { asphalt may be incorporated, as the } \\
\text { crystalline growth induces } \\
\text { 'eruptions' in the seal caused by } \\
\text { volume changes in the basecourse. }\end{array}$ \\
\hline
\end{tabular}

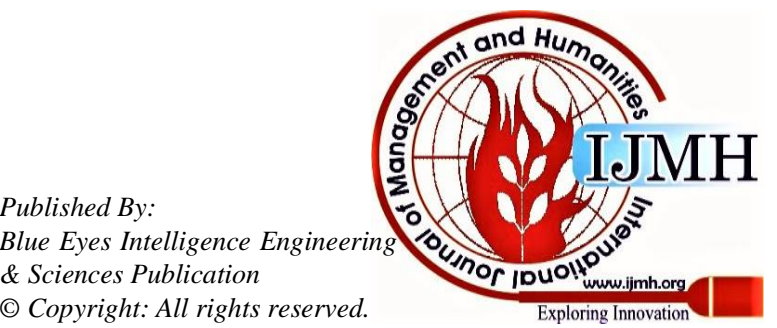




\section{Combinations:}

There is an increasing range of road stabilizing products being developed and patented that fall under the above categories or combinations thereof. The bulk of products introduced to the Roads Authority in recent years were either chemical, or a combination of the various categories indicated above.

Synthetic polymer binders/stabilizers consist primarily of either PVA, PVC or PAM (acrylamide) polymers, whereby the polymers bond fine particles and impart hydrophobic properties to the soil. They are generally effective in sandy soils, with lime added for application in clays.

This review does not include the environmental aspects of cementitious or bituminous stabilizers, as these have been in use for decades.

Synthetic polymers are either water soluble or water insoluble.

- Insoluble Dry Powdered Synthetic Polymer (IDPSP): dry powdered road stabilising binder consisting of an insoluble polymer thermally bound to a very fine carrier such as fly ash;

- Synthetic Soluble Polymers: polymer forming liquids that encapsulate and bind soil particles;

- Organic: generally a by-product of timber pulp or citrus industries, consisting of either sulphonated lignin, tall oil pitch, or sulphonated di-limonene;

- Ionic: highly ionic derivates of sulphonated petroleum products;

- Salts: salts can be used in areas where the atmospheric moisture falls below a certain level. Salts bind particles by attracting and trapping moisture from the air, keeping the road surface moist. Best suited to clay soils;

- Enzymatic: enzyme rich liquids that react with organic molecules in order to achieve an intermediary reactive that exchange ions with clayey structures. This effect generates a cemented bond, which stabilizes the soil structure and reduces its affinity for water.

Within the different categories, those based on cementitious, bituminous and enzymatic processes were excluded from the study at the request of the Client.

During any particular construction project, stabilising agents will be subjected to transportation, storage and application phases and any environmental assessment must consider the potential impacts of each stage.

A limited duration is generally allowed for mixing and setting processes during construction. Once the product is activated by addition of water and processing of the materials commences the chemical processes involved commence. Application of specialized stabilizers requires specialized supervision and strict control of the construction process. Most of the stabilizing process also involves use of specialized equipment, such as Recyclers or Rotovators.

Introduction of the stabilizer product into the pavement material is usually achieved as follows:

i. spreading or placing the stabilizing agent on the pavement material or spraying onto a windrow before processing commences; ii. injection into the rotating drum chamber of a Recycling machine from a tanker during a recycling pass;

iii. premixing the stabilizing agent into the pavement material at a batch plant and subsequent importing the material onto the road section.

Standards for Contractors should make provision for spillages and remediation thereof and in particular, proper standards should be set for working with stabilizing agents that are potentially hazardous.

The range of the 20 stabilizer products considered are listed in the Appendix.

\section{ENVIRONMENTAL REQUIREMENTS}

The environmental requirements for a binder seeking approval for use relates to the potential for adverse impacts on the surrounding environment arising from its use, both during application and post-application (over time), due to wear and weathering.

Vendors wishing to sell their product into a market should be required to apply to be accepted onto an approved materials supplier list. To facilitate the review of available products, all information should be presented or made available in a summary sheet accompanying the information, including the following details:

- composition;

- testing certification;

- application;

- physical/chemical properties and hazards/toxicity;

- atmospheric concentrations;

- setting time;

- additional information

In terms of potential environmental effects, acceptance onto the list should be based a range of criteria, key amongst which is the product Material Safety Data Sheet (MSDS) and other chemical safety data as available. The MSDS data should provide a set of minimum requirements that provide sufficient data to allow an assessment of the potential environmental impacts arising from use of the substance in specific environmental settings.

Physical/chemical properties and hazards/toxicity factors to be considered when assessing a stabilizer should include:

- solubility;

- leachate;

- toxicity;

- carcinogenicity;

- corrosiveness;

- hazardous;

- acid forming potential

The UN document, Globally Harmonized System of Classification and Labelling of Chemicals (GHS) Part 4 (Ref. 3), Environmental Hazards, aquatic environment, sets out the range of tests that can be applied to assess the potential impact of a chemical on the aquatic environment.

The necessary data to allow a decision on the suitability of a particular binder and its potential environmental impact is characteristically more extensive than that provided by the vendor.

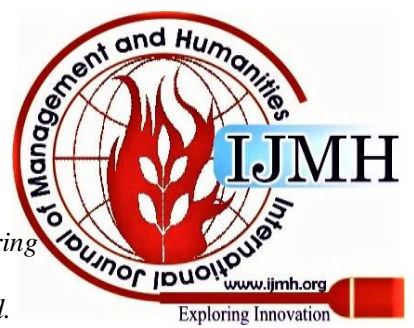


The basic minimum information that each binder should have available is usually found in the MSDS, safety data sheet (SDS), or product safety data sheet (PSDS). Test data cited in these data sheets is based on the UN document but in a much-reduced form.

In addition to environmental data, other requirements needed for assessment and acceptance of an application should include the name of the vendor, name of the product, any patent information and a full product description.

The subsequent assessment of the potential impact of a stabilizer will depend not only on the properties of the stabilizer but also the particular environmental setting and how/when the binder is applied. In terms of 'application', this refers to both the initial stage involving placement of the stabilizer when spills can occur and once fully reacted and placed and its subsequent performance over the years.

Hence, while each application will be specific in terms of the combination of stabilizer and road materials used and the environmental setting, it is possible to set out general guidelines that will assist users make an appropriate, initial assessment of the suitability of a particular binder if used in a particular environmental setting.

Table 1 presents the data available for each of the 20 stabilizer products considered, which covers a range of factors, including the type/category of stabilizer, product description, MSDS environmental data, solubility, biodegradability, inertness and leachability. The 48h, mg/l, LC50 test is based on using Daphnia, upper 95\% confidence level and the $72 \mathrm{~h}, \mathrm{mg} / \mathrm{l}, \mathrm{EC50}$ test is the algal growth inhibition test.

Not all MSDS contain LC(50) and EC(50) data. Of the 20 stabilizer products considered, some toxicity information/data was provided by seven vendors but only one provided data for both toxicity tests.

\section{BREAKDOWN PRODUCTS IN THE ENVIRONMENT}

Key factors that may lead to releases into the environment are:

- inherent toxicity and/or harmful characteristics of pre-cursor substances (chemicals) used in road stabilisation and how they are stored and handled;

- the initial application stage and incorporation of the stabilizer with the road construction material, when an excessive amount may be applied or a spillage may occur;

- breakdown of the binder in the longer term leading to chronic environmental release.

In the case of the latter, important factors are the extent to which a product breaks down and the nature of the breakdown products arising. Standardised leaching tests are used to simulate the possible breakdown products generated and assess the effects of the products on the water environment. The UN document, Globally Harmonized System of Classification and Labelling of Chemicals (GHS) Part 4 describes the terms that relate to the hazardous properties of chemicals and their impact on the aquatic environment.

The basic elements for use within the harmonised system are (Ref. 4):

- acute aquatic toxicity;

- potential for or actual bioaccumulation;

- degradation (biotic or abiotic) for organic chemicals; and

- chronic aquatic toxicity

While data from internationally harmonised test methods are preferred, in practice, data from national methods may also be used, where they are considered as equivalent. In general, it has been agreed that freshwater and marine species toxicity data can be considered as equivalent data; preferably derived using OECD Test Guidelines or equivalent. Where such data are not available, classification should be based on the best available data.

Two commonly referenced tests in relation to aquatic impacts are the 48h $\mathrm{LC}(50)$ and $72 \mathrm{~h} \mathrm{EC(50)}$ tests. In the LC(50) test fish (or aquatic organisms) are exposed to the test substance, preferably for a period of 96 hours. Mortalities are recorded at 24, 48, 72 and 96 hours and the concentrations that kill $50 \%$ of the organisms (LC50) are determined where possible.

The purpose of the EC(50) test is to determine the effects of a substance on the growth of fresh water microalgae (algae and cyanobacteria). Exponentially growing test algae are exposed to the test substance in batch cultures over a period, normally 72 hours. The test endpoint is inhibition of growth, expressed as logarithmic algal biomass increase (average growth rate) during the exposure period. From the average growth rates recorded in a series of test solutions and the concentration bringing about a specified $\mathrm{X} \%$ inhibition of growth, usually $50 \%$, is determined and expressed as the ECx e.g. EC50.

In simple terms the LC50 (mg/L) test results presented for a product can be interpreted as follows in Table 1 .

Table 1: Toxicity tests

\begin{tabular}{|c|l|}
\hline LC50 (mg/L) & Category Description \\
\hline$<0.1$ & Very highly toxic \\
\hline $0.1-1$ & Highly toxic \\
\hline $1-10$ & Moderately toxic \\
\hline $10-100$ & Slightly toxic \\
\hline$>100$ & Practically non-toxic \\
\hline
\end{tabular}

Lignosulphonate products sold for road de-dusting are separated spent liquor (SSL) concentrates. When removing water in evaporators sulphur dioxide, acetic and formic acids are distilled off, leaving liquors that are less toxic than the raw material. Published information about various lignosulfonates are summarised in Table 2.

Table 2: Toxicity of water soluble materials on fish

\begin{tabular}{|c|c|c|c|}
\hline 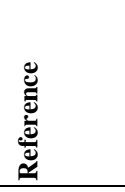 & 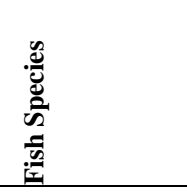 & 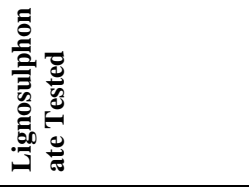 & \& ڤ \\
\hline Wilson & Rainbow Trout & $\begin{array}{l}\text { Lignosol } \\
\text { (Quebec) }\end{array}$ & 3,700 \\
\hline Stapanian & Rainbow Trout & $\begin{array}{l}\text { Lignosite (West } \\
\text { Coast) }\end{array}$ & 2,125 \\
\hline Wilson & Rainbow Trout & Lignosol XD & 3,500 \\
\hline
\end{tabular}




\begin{tabular}{|l|l|l|l|}
\hline Roald & Rainbow Trout & $\begin{array}{l}\text { Purified Na } \\
\text { Lignosulphonate }\end{array}$ & 7,300 \\
\hline Canada & Various & Calcium Chloride & 5,000 \\
\hline Jones & Various & Sodium Chloride & 6,000 \\
\hline Jones & $\begin{array}{l}\text { Fathead } \\
\text { Minnows }\end{array}$ & Sodium Sulphate & 9,000 \\
\hline Jones & $\begin{array}{l}\text { Fathead } \\
\text { Minnows }\end{array}$ & $\begin{array}{l}\text { Tide Laundry } \\
\text { Detergent }\end{array}$ & 50 \\
\hline Jones & $\begin{array}{l}\text { Fathead } \\
\text { Minnows }\end{array}$ & $\begin{array}{l}\text { Sodium } \\
\text { Dodecylbenzene } \\
\text { Sulphonate }\end{array}$ & 4 \\
\hline Jones & $\begin{array}{l}\text { Fathead } \\
\text { Minnows }\end{array}$ & $\begin{array}{l}\text { Sodium Lauryl } \\
\text { Sulphate }\end{array}$ & 5 \\
\hline
\end{tabular}

Evaporating water and volatiles from dilute calcium and sodium SSL substantially reduces toxicity to the point where fish can tolerate 3,000 rather than $1,000 \mathrm{mg} / \mathrm{l}$ of solids. With purified lignosulphonates the tolerance is increased to 7,000 mg/l (Ref. 5). The common salts calcium chloride, sodium chloride and sodium sulphate have $\mathrm{LC}_{50}$ 96-hour values in the 5,000 - 10,000 range (Ref. 6). Other data references the cut-off point for $\mathrm{LC}_{50}$ 96-hour values as $1,000 \mathrm{mg} / \mathrm{l}$. Compounds with values greater than this are given a value of $>1,000$ and are considered to have a low order of toxicity. Calcium and sodium lignosulfonates, calcium chloride, sodium chloride and sodium sulphate all are in this category. In contrast, a popular laundry detergent Tide and surfactants used in making these products are toxic toward fish (Ref. 7), with values ranging from $4-50 \mathrm{mg} / \mathrm{l}$ reported for these materials.

\section{POTENTIAL ENVIRONMENT IMPACTS OF STABILIZERS AND BREAKDOWN PRODUCTS}

The potential environmental impact of stabilizers and their breakdown products is determined by both the chemical properties of the stabilizer/binder and its effective use and incorporation into the road materials.

Improper placement/incorporation of the stabilizers/binders is likely to result in greater environmental impacts than the resultant stabilised road structure. Poor storage, management, handling and application of the chemicals during application can result in spillages and release into the aquatic environment. Unless prompt remedial action is taken the impact of such spills is likely to far outweigh any long-term environmental impacts of the in situ, stabilised material.

Equally important is proper preparation of the road material(s) and adequate mixing/incorporation of the chemical into the road materials is important to reduce the quantity of any unreacted chemicals remaining and being released into the environment.

Data on the resultant breakdown products of the range of stabilizers/binders covered by the study is limited. A few vendors have provided useful data but most have not. In these latter cases reliance is left to any published information/data on the chemicals used, which is often quite generic and not targeted at the specific conditions experienced by a road i.e. intermittent flooding, cracking etc.

\section{A. Acrylamide}

Polyacrylamide or poly(1-carbamoylethylene)) is a polymer (-CH2CHCONH2-) formed from acrylamide subunits. While the main source of acrylamide in the environment is man-made, due primarily to the release of monomer residues from polyacrylamides used in water treatment and industry, acrylamide is also a naturally occurring by-product of the cooking food. Production of acrylamide occurs naturally in a wide variety of foods when they are heated or cooked, including coffee, chocolate, almonds, potato chips, cereal, bread and some fruits and vegetables.

Due to its highly solubility in water, acrylamide is extremely mobile in the aqueous environment and readily leachable in soil. In dilute aqueous solution applications, polyacrylamide polymers are susceptible to chemical, thermal, and mechanical degradation.

Chemical degradation occurs when the labile amine moiety hydrolyzes at elevated temperature or $\mathrm{pH}$, resulting in evolution of ammonia and a remaining carboxyl group, increasing the degree of anionicity of the molecule. Thermal degradation of the vinyl backbone can occur through several possible radical mechanisms, including auto-oxidation of small amounts of iron and reactions between oxygen and residual impurities from polymerization at elevated temperature. Cross-linked variants of polyacrylamide have shown greater resistance to all these methods of degradation and proved more stable.

There are insufficient epidemiological data regarding occupational or environmental exposure to acrylamide to serve as a basis for a quantitative risk evaluation. Experimental animal data indicate that there are no major species differences among mammals with respect to acrylamide metabolism or sensitivity to its neurotoxic effects. Extrapolation from animal dose-effect data suggests that an absorbed dose of $0.12 \mathrm{mg} / \mathrm{kg}$ body weight per day (derived from total dose to surface area data) could cause adverse neurological effects in man. As acrylamide is readily absorbed through the skin and by inhalation and ingestion, these effects are probably independent of the route of exposure. Applying a safety factor of 10 to the extrapolated minimum dose for neurological effects would indicate that an absorbed dose of $0.012 \mathrm{mg} / \mathrm{kg}$ body weight per day should not be exceeded. Animal data are not sufficient to draw any conclusions concerning the carcinogenicity of acrylamide. Acrylamide is associated with adverse effects on testicular function in experimental animals. No data regarding these effects in human beings are available. Biodegradation is likely to occur, as a number of microbes possess the ability to degrade acrylamide. However, there is a latent period of several days before any significant degradation, so the residence period for acrylamide may be of the order of days, weeks, or months in rivers and coastal areas of low microbial activity. The halflife in aerobic soil is of the order of several days at $20^{\circ} \mathrm{C}$, increasing with decreasing temperature. Concerns have been raised that polyacrylamide used in agriculture may contaminate food with the nerve toxin acrylamide.

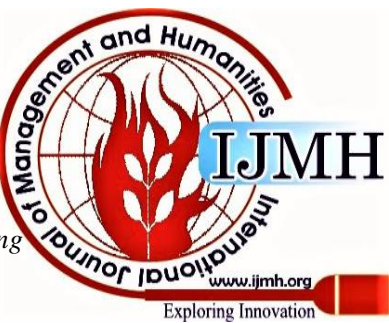


While polyacrylamide itself is relatively non-toxic, it is known that commercially available polyacrylamide contains minute residual amounts of acrylamide remaining from its production, usually less than $0.05 \%$ w/w (Ref. 8).

There are concerns that polyacrylamide may de-polymerise to form acrylamide. In a study conducted in 2003 at the Central Science Laboratory in Sand Hutton, England, polyacrylamide was treated similarly as food during cooking. It was shown that these conditions do not cause polyacrylamide to de-polymerise significantly (Ref. 9). As of 2010, California requires products containing acrylamide as an ingredient to be labelled with a statement that it is "a chemical known to the State of California to cause cancer."

In a study conducted in 1997 the effect of environmental conditions on polyacrylamide were tested and it showed that degradation of polyacrylamide under certain conditions does in fact cause the release of acrylamide (Ref. 10). However, the experimental design of the study, as well as its results and interpretation, has been questioned (Refs. 11 and 12) and a 1999 study could not replicate the results (Ref. 13).

\section{B. Hygroscopic and Deliquescent Chemicals}

Deliquescent chemicals, such as calcium chloride and sodium chloride, attract water from the atmosphere, helping to maintain a moisture film around soil particles that binds particles together. Dust suppression using this method is therefore effective if the humidity of the air is high enough to provide the water.

Limited information is available on the environmental impact of hygroscopic and deliquescent chemicals when used as dust suppressant agents. Salts applied for dust suppression initially penetrate the road to a depth of several centimetres and then rise to the surface by capillarity action, making them susceptible to being washed off by rain. The environmental impact of the resulting runoff will be similar to that of the particular salt used and is dependent on the concentration of salt in this runoff.

\section{Organic Binders/Lignosulphonates}

Most organic binders used as dust suppressants are lignosulphonate compounds, water soluble liquid chemical by-products of the sulphite pulping process. There are five types of lignosulphonate compounds: crude lignosulphonate, calcium lignosulphonate; sodium lignosulphonate; magnesium lignosulphonate; and ammonium lignosulphonate.

Sugars and carbohydrates are easily fermented by many different microbes and with as much as $35 \%$ of these easily fermented substances present in lignosulphonate and few toxic materials around, partial decay occurs quickly (Ref. 14). Because of the wood sugars, lignosulphonates are not added to waterways containing fish and a marginal supply of dissolved oxygen, as the microbes will feed on the sugars and consume oxygen in the process.

Results of many tests on basic lignosulphonates indicate the five-day Biochemical Oxygen Demand $\left(\mathrm{BOD}_{5}\right)$ as $0.23 \mathrm{~kg} / \mathrm{kg}$ solids i.e. $45 \mathrm{~kg}$ lignin mixed with $1,500 \mathrm{~m}^{3}$ water containing 11ppm dissolved oxygen, to end up after five days with water containing 4ppm dissolved oxygen. The concentration of 4ppm dissolved oxygen is where fish kill first appears. This means 30ppm SSL solids allows a safe level dissolved oxygen to be present. More complex lignosulphonates show even lower $\mathrm{BOD}_{5}$ values.
During the 1960s attention was given to laundry detergents discharged to waterways that produced voluminous and persistent foam. The test developed for assessing the foaming ability of new surfactants for washing powders was applied also to examine the effects of lignosulphonates. Small amounts of lignosulphonates dissolved in aerated river water are held at room temperature for 33 days and samples removed periodically and tested for organic matter content, by oxidising with dichromate to determine the Chemical Oxygen Demand (COD). Data showed that Norlig A, a lignosulphonate road binder material, degraded $28 \%$ in five days and $43 \%$ in 33 days. This closely corresponds to the carbohydrate content of the product and indicates that pure lignin resists decay. The $54 \%$ material remaining after 33 days of incubation persisted as a road binder and shows as a natural lignin colour in waterways, similar to the situation of the brown colour imparted to streams and lakes by humus and humic acids produced by the decay of plants and trees.

The overall impact on the environment from applying lignosulphonates to roads is negligible. They are safer to use for stabilisation and dust control than any competing class of chemicals. The manufacture of lignin involves evaporation; the evaporation process drives off any volatile contaminants such as acetic acid. Corrosion and toxicity towards plants can be readily minimised by $\mathrm{pH}$ control and lignosulphonates are non-toxic to animals.

- no dioxins present;

- no other organics present at hazardous levels;

- toxic trace minerals are below EP Toxicity limits;

- low order of toxicity towards fish;

- non-toxic orally and non-irritating to the skin or eyes of animals;

- no human health problems attributed to exposure;

- very low toxicity towards plants;

- residuals are resistant to decay.

When spread on land there is no risk of contaminating ground water. Published data indicates that at $<10 \mathrm{kgs} / \mathrm{m}^{2}$, no problems arise. This value is much above the $1 \mathrm{~kg} / \mathrm{m}^{2}$ required for stabilisation and $0.3 \mathrm{~kg}$ used typically for dust control.

\section{Ionic Stabilizers}

Investigations (Ref. 15) have shown that treatment with Sulphonated Petroleum Products (SPPs) can have a significant beneficial effect on the strength of certain soils. It has also shown that only some materials can be improved with SPP treatment and some SPP products only affect certain, mostly clayey soils.

Where the combination of soil and chemical is correct, strength increases of $+100 \%$ can be achieved and even higher in practice. In many cases where SPPs are used, construction controls are reduced, or ignored. It is important that ongoing, rigorous quality control procedures are applied to the quantity of binder/stabilizer added and its proper incorporation into the soil, as assessed by materials control and density testing procedures.

Published By: Blue Eyes Intelligence Engineering \& Sciences Publication (C) Copyright: All rights reserved. 
All SPP chemicals are classified as ionic soil stabilizers that rely on replacing/bonding with cations in the clays used. It is essential to evaluate any changes that may occur with both the stabilizer chemical used and clay soil applied to, as these can affect both the physical and environmental performance of the final product.

Aluminium oxide in 'unsuitable' lateritic soils (comprising mostly silica, aluminium oxide and ferric oxide) may react with the acidic ISS 2500 stabilizer during stabilization to form salts. "Salts" are formed when the $\mathrm{H}^{+}$ ions of the acid are replaced by $\mathrm{OH}^{-}$ions. Ferric oxide in unsuitable soils may react slowly with the acid of the ISS 2500 to form $\mathrm{Fe}^{+++}$salts and may also react with the alkali to form ferrates. This may take place as a secondary effect after stabilization, as the action takes place slowly.

\section{CLASSIFICATION AND RANKING STABILISATION PRODUCTS}

\section{A. Product types}

The stabilizer products considered within this study are classified broadly as:

- Insoluble Dry Powdered Synthetic Polymers (IDPSP);

- Synthetic Soluble Polymers;

- Organic Lignosulphonates;

- Ionic Stabilizers; and

- Salts.

Within these broad classifications, products were subdivided as follows:

- Insoluble Dry Powdered Synthetic Polymers: products considered within this classification are subdivided in to those that contain lime and those that do not. Of the products considered within this classification, only one did not contain lime.

- Synthetic classification is subdivided in to bituminous products and non-bituminous products, mainly acrylamides, acrylates and vinyl polymers.

- Organic Lignosulphonates: there are no subdivisions within this classification.

- Ionic Stabilizers: there were two products within this classification considered.

- Salts: there was only one product within this study that was a salt.

\section{B. Ranking}

Each of the products considered within the study are suitable for the purpose of road building. Consideration must be made of the area within which they are to be used and thus the classes of product are ranked with respect to the type of area within which they are to be used. The road stabilizer product classifications are considered both with respect to environmental impact as well as health and safety impacts.

Consideration was also made of potential impacts:

- on application (including on-site storage prior to use);

- when the road has been constructed; and

- on long terms degradation and decomposition.

The main areas for concern when using these products are application in and near to wetlands or water courses.
Wetlands include areas where there are omuramba, permanent river systems (including their flood plains) and lakes, both permanent and ephemeral. However, even in areas considered as non-wetlands, care must be taken on application and on-site storage to prevent contamination of hand dug wells, or omifima.

Table 3 shows the ranking of the road stabilisation product types in terms of health and safety and environmental concerns only, where 1 produces the least impact. The civil engineering performance and structural stability of the products and their suitability for use with different soil types has not been considered within the scope of this study.

It is strongly recommended that a full, comprehensive testing programme to assess the structural performance of the soil/product mix is undertaken, both to ensure the necessary engineering performance is achieved and importantly, to confirm the correct mix proportions and placement conditions required.

The manufacturer's protocols for storage/handling/use should always be adhered to.

It should be noted that once the roads have been constructed the products used have negligible health and safety and environmental impacts. However, as with all the products, a precautionary approach must be taken to ensure that no contamination of the water environment occurs. This is particularly true in areas where ephemeral lakes and rivers occur, as it cannot be certain when these water bodies will be present.

\section{CONCLUSIONS}

Road infrastructure is key for any country to enable its development, especially in developing countries such as those in Africa.

Natural road construction materials used historically can become depleted and increasing traffic loads produce higher road maintenance requirements. As a consequent research is ongoing to develop additives that can be used to enhance the engineering properties of the available soils.

Roads in rural areas must usually work with the available soils and make them suitable for use as a road bearing material, able to be used by large vehicles in all weathers. This process requires compaction and stabilisation of the soil, achieved by the combination of civil engineering measures to form the road surface and use of chemical additives or soil stabilizers to allow a compacted road surface to be formed.

Namibia, SW Africa, especially the northern region, has scarce road building materials and requires the use of road stabilizers to extend and maintain the road network. A number of stabilizer products are available and the choice of stabilizer must take into account both the specific properties of the stabilizer and sensitivity of the environment where the stabilizer is to be used, to ensure any potential adverse environmental impacts are avoided wherever possible or at least minimised;

Published By: Blue Eyes Intelligence Engineering \& Sciences Publication (C) Copyright: All rights reserved. 
Recognising this need the Roads Authority of Namibia commissioned a review to ascertain the potential environmental and health related impacts of such products and how to apply their use in a responsible manner. The northern region of Namibia comprises an environment sensitive to the potential adverse impacts of materials that released into the environment, either during construction or subsequently as breakdown products. Much of the region contains aquatic ecosystems and as such, aquatic life is sensitive to toxins and water can transport contaminants long distances.

The main stabilizer types are cementitious, bituminous and chemical, with the latter broken down in a range of materials including synthetic polymer binders, organic and ionic compounds, salts, enzymatic products and combinations thereof.

Due to their long term, widespread use, cementitious and bituminous products are well characterised and excluded from the study. 
Table 3: Environmental ranking of stabilizer types

\begin{tabular}{|c|c|c|c|c|c|c|c|c|}
\hline \multirow{2}{*}{\multicolumn{2}{|c|}{ Stabilizer Class }} & \multicolumn{2}{|c|}{ Application (including storage on site) } & \multicolumn{2}{|c|}{ In Use } & \multicolumn{2}{|c|}{ Decomposition } & \multirow{2}{*}{$\begin{array}{c}\text { Rankin } \\
\text { g }\end{array}$} \\
\hline & & $\mathrm{H} \& \mathrm{~S}$ & Environment & H\&S & Environment & $\mathrm{H} \& \mathrm{~S}$ & $\begin{array}{c}\text { Environmen } \\
t\end{array}$ & \\
\hline \multirow[t]{2}{*}{ IDSPS } & Lime & $\begin{array}{l}\text { Potential to cause burns } \\
\text { to skin and eyes. If } \\
\text { inhaled may cause } \\
\text { serious burns to lungs } \\
\text { and nasal passages }\end{array}$ & $\begin{array}{l}\text { If lime gets into the water environment } \\
\text { it will raise the } \mathrm{pH} \text { and react } \\
\text { exothermically. It has the potential to } \\
\text { cause significant, short term } \\
\text { environmental harm. However, if these } \\
\text { products enter an omuramba } \\
\text { /ephemeral water body the } \\
\text { environmental consequences could be } \\
\text { longer term and more significant. }\end{array}$ & $\begin{array}{l}\text { Durability of the road surface is } \\
\text { unknown, but erosion and abrasion } \\
\text { may give rise to particulate matter. } \\
\text { If } \mathrm{PM}_{10} \text { are produced this may have } \\
\text { concern if inhaled. However, dust } \\
\text { particulates will be naturally } \\
\text { generated through wind action and } \\
\text { thus the impact on } \mathrm{H} \& \mathrm{~S} \text { from is } \\
\text { minimal in comparison. }\end{array}$ & $\begin{array}{l}\text { Once set the leachability is low and } \\
\text { thus unlikely to cause any } \\
\text { contamination of water bodies. If } \\
\text { the product has been badly mixed } \\
\text { there may be a surfeit of lime, } \\
\text { which may leach into water bodies, } \\
\text { thus significant care must be given } \\
\text { to preparation and application to } \\
\text { prevent future harm once the road } \\
\text { has been constructed. }\end{array}$ & $\begin{array}{l}\text { Not } \\
\text { considered } \\
\text { significant }\end{array}$ & $\begin{array}{l}\text { Not } \\
\text { considered } \\
\text { significant }\end{array}$ & 2 \\
\hline & No Lime & Negligible & $\begin{array}{l}\text { Negligible, although care should be } \\
\text { taken to prevent contamination of } \\
\text { drinking water. }\end{array}$ & Negligible & Negligible & $\begin{array}{c}\text { Not } \\
\text { considered } \\
\text { significant } \\
\end{array}$ & $\begin{array}{c}\text { Not } \\
\text { considered } \\
\text { significant } \\
\end{array}$ & 1 \\
\hline \multirow[t]{2}{*}{$\begin{array}{l}\text { Synthetic } \\
\text { Soluble } \\
\text { Polymers }\end{array}$} & Bituminous & $\begin{array}{l}\text { Bitumen contains } \\
\text { carcinogenic substances, } \\
\text { and although not } \\
\text { classified as a } \\
\text { carcinogen, care must be } \\
\text { taken when using these } \\
\text { products, based upon the } \\
\text { precautionary principle } \\
\end{array}$ & $\begin{array}{l}\text { Although not considered toxic to } \\
\text { aquatic organisms since these products } \\
\text { are liquids, care should be taken in } \\
\text { storage and application to ensure they } \\
\text { do not enter water courses to ensure } \\
\text { contamination of drinking water does } \\
\text { not occur. }\end{array}$ & $\begin{array}{l}\text { Essentially non-hazardous once } \\
\text { cured. }\end{array}$ & $\begin{array}{l}\text { Essentially non-hazardous once } \\
\text { cured }\end{array}$ & $\begin{array}{l}\text { Not } \\
\text { considered } \\
\text { significant }\end{array}$ & $\begin{array}{l}\text { Not } \\
\text { considered } \\
\text { significant }\end{array}$ & 2 \\
\hline & $\begin{array}{c}\text { Non- } \\
\text { bituminous }\end{array}$ & $\begin{array}{l}\text { Considered non- } \\
\text { hazardous }\end{array}$ & $\begin{array}{l}\text { Considered non-hazardous but as these } \\
\text { products are liquid, care must be taken } \\
\text { in storage and use to ensure they do not } \\
\text { enter water courses to prevent } \\
\text { contamination of drinking water } \\
\text { occurring. } \\
\end{array}$ & Negligible & Negligible & $\begin{array}{c}\text { Not } \\
\text { considered } \\
\text { significant }\end{array}$ & $\begin{array}{l}\text { Not } \\
\text { considered } \\
\text { significant }\end{array}$ & 1 \\
\hline \multicolumn{2}{|c|}{ Organic Lignosulphonates } & $\begin{array}{l}\text { Essentially non- } \\
\text { hazardous }\end{array}$ & $\begin{array}{l}\text { Essentially non-hazardous, although } \\
\text { care should be taken to ensure they do } \\
\text { not enter water courses to prevent } \\
\text { contamination of drinking water. } \\
\end{array}$ & Negligible & Negligible & $\begin{array}{l}\text { Not } \\
\text { considered } \\
\text { significant }\end{array}$ & $\begin{array}{l}\text { Not } \\
\text { considered } \\
\text { significant }\end{array}$ & 1 \\
\hline \multicolumn{2}{|c|}{ Ionic Stabilizers } & $\begin{array}{c}\text { Can be acidic and thus } \\
\text { may cause burns to skin } \\
\text { and eyes. If inhaled } \\
\text { significant burns may } \\
\text { occur to lungs and nasal } \\
\text { passages } \\
\end{array}$ & $\begin{array}{l}\text { Claims to be environmentally safe but } \\
\text { if acidic, may cause deleterious effects } \\
\text { if entering water bodies. Care must be } \\
\text { taken to ensure pollution of water } \\
\text { courses does not take place during } \\
\text { storage and handling. } \\
\end{array}$ & $\begin{array}{l}\text { Essentially non-hazardous once } \\
\text { cured. }\end{array}$ & $\begin{array}{c}\text { Essentially non-hazardous once } \\
\text { cured }\end{array}$ & $\begin{array}{c}\text { Not } \\
\text { considered } \\
\text { significant }\end{array}$ & $\begin{array}{l}\text { Not } \\
\text { considered } \\
\text { significant }\end{array}$ & 2 \\
\hline \multicolumn{2}{|c|}{ Salts } & $\begin{array}{l}\text { Considered non- } \\
\text { hazardous }\end{array}$ & $\begin{array}{l}\text { Care must be taken during storage and } \\
\text { application, to prevent contamination of } \\
\text { water bodies. }\end{array}$ & $\begin{array}{c}\text { Essentially non-hazardous once } \\
\text { cured. }\end{array}$ & $\begin{array}{c}\begin{array}{c}\text { Essentially non-hazardous once } \\
\text { cured }\end{array} \\
\end{array}$ & $\begin{array}{c}\text { Not } \\
\text { considered } \\
\text { significant } \\
\end{array}$ & $\begin{array}{c}\text { Not } \\
\text { considered } \\
\text { significant } \\
\end{array}$ & 1 \\
\hline \multicolumn{3}{|c|}{$\begin{array}{l}\text { Retrieval Number: J09860641020/2020@BEIESP } \\
\text { DOI:10.35940/ijmh.J0986.0641020 } \\
\text { Journal Website: } \text { www.ijmh.org }\end{array}$} & \multicolumn{3}{|c|}{$\begin{array}{l}\text { Published By: } \\
\text { Blue Eyes Intelligence Engineering } \\
\text { \& Sciences Publication } \\
\text { () Copyright: All rights reserved. }\end{array}$} & & & \\
\hline
\end{tabular}


In terms of testing the UN document, "Globally Harmonized System of Classification and Labelling of Chemicals (GHS) Part 4, Environmental Hazards, aquatic environment", sets out the range of tests that can be applied to assess the potential impact of a chemical on the aquatic environment. Tests include product description, MSDS environmental data, solubility, biodegradability, inertness and leachability, with the $48 \mathrm{~h}, \mathrm{mg} / \mathrm{l}, \mathrm{LC} 50$ test based on using Daphnia, upper 95\% confidence level and 72h, mg/l, EC50 test is an algal growth inhibition test.

A total of 20 stabilizer products were reviewed in terms of the above criteria but only general findings for the main product types are reported in this paper. All road binders and soil stabilizer products reviewed are in widespread use across the world in different climates and underlying geology. Despite the apparent lack of documented supporting material for some products, it is was assumed the products were accepted or authorised by the appropriate road authority for use in those countries.

In general terms the environmental impact of stabilizers and any breakdown products is determined by the chemical properties of the stabilizer/binder and its effective use and incorporation into the road materials.

Factors such as poor storage, management, handling and application of the chemicals during application can result in spillages and release into the aquatic environment and unless prompt remedial action is taken the impact of such spills is likely to far outweigh any long-term environmental impacts of the in situ stabilised material.

The most significant problems are likely to arise from poor construction practices associated with the transport, storage, handling and disposal of the drums and containers used, combined with inadequate mixing and poor placement practices i.e. insufficient/too much water or product, poor compaction, insufficient curing/reaction time etc. Some stabilizer products can be harmful and/or toxic to the surrounding environment and human health, prior to being mixed and reacted fully. If incorrectly applied the stabilised road base may have the potential to release substances in the short/medium term due to overuse of one or more of the chemicals involved etc.

In terms of the overall ranking of the environmental impact of stabilizer types, much depends on the specific setting and product used. In general, product types with the highest i.e. best, environmental ranking are: no lime IDPSP, non-bituminous synthetic soluble polymers, organic lignosulphonates and salts;

Road stabilizers play an important role in providing transport infrastructure in developing countries but when used in sensitive environments, especially aquatic settings, full account of the material properties, including any breakdown products, need to be taken into account.

When the stabilizers have been mixed correctly and applied properly, they create a stable, relatively inert matrix with the soil. The main conclusion of the review is that with proper handling and application, most if not all stabilizers, pose few, long-term, toxicity effects.

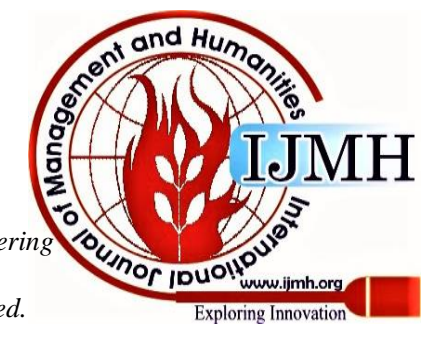


APPENDIX: STABILIZERS REVIEWED

\begin{tabular}{|c|c|c|c|c|c|c|c|c|c|c|c|c|}
\hline$\dot{z}$ & 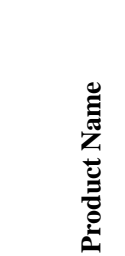 & 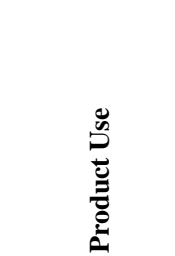 & 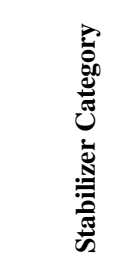 & 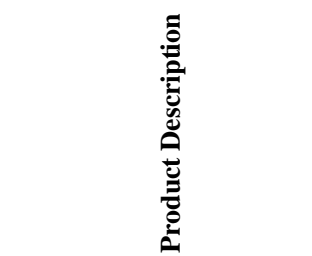 & 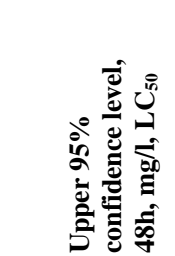 & 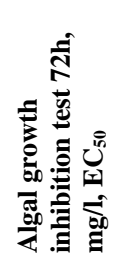 & 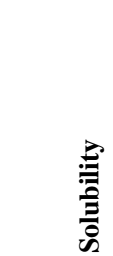 & 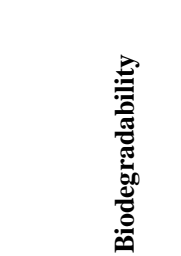 & 总 & 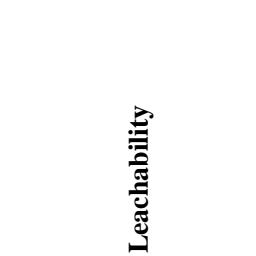 & 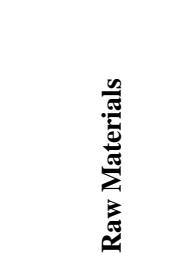 & 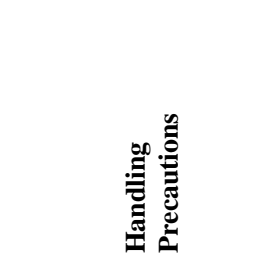 \\
\hline 1 & $\begin{array}{l}\text { ANSS- } \\
\text { Anyway } \\
\text { Soil } \\
\text { Stabilizer }\end{array}$ & Soil stabilizer & IDPSP & $\begin{array}{l}\text { Inorganic hydration } \\
\text { activated powders } \\
\text { composed of a specific } \\
\text { type of cement, a lime, } \\
\text { several pozzolans, rate } \\
\text { governing additives, and a } \\
\text { unique polypropylene } \\
\text { fibre. Heavy metals - } \\
\text { natural in origin nothing } \\
\text { added even if present then } \\
\text { stabilised at high pH. }\end{array}$ & 1.62 & $10-25$ & Low & $\begin{array}{l}\text { Material is not } \\
\text { expected to } \\
\text { significantly } \\
\text { bioaccumulate }\end{array}$ & $\begin{array}{l}\text { No data } \\
\text { available }\end{array}$ & $\begin{array}{l}\text { Low. Concentration } \\
\text { of transition } \\
\text { elements in leachate } \\
\text { is below primary } \\
\text { drinking water } \\
\text { standards, while Co } \\
\text { and Pb are only } \\
\text { slightly above. } \\
\text { Non-toxicity } \\
\text { recognised by Green } \\
\text { Label award, } \\
\text { Ministry of the } \\
\text { Environment and the } \\
\text { Standards Institute, } \\
\text { Israel. }\end{array}$ & $\begin{array}{l}\text { Main } \\
\text { components are } \\
\text { a series of } \\
\text { inorganic } \\
\text { hydration } \\
\text { activated } \\
\text { powders. It is } \\
\text { composed of a } \\
\text { specific type of } \\
\text { cement, a lime, } \\
\text { several } \\
\text { pozzolans, rate } \\
\text { governing } \\
\text { additives, and } \\
\text { polypropylene } \\
\text { fibre. }\end{array}$ & $\begin{array}{l}\text { Use gloves, shoes and } \\
\text { protective clothing to } \\
\text { prevent skin contact. } \\
\text { Contaminated clothing } \\
\text { should be removed } \\
\text { and the skin washed } \\
\text { with soap and water or } \\
\text { an appropriate skin } \\
\text { cleanser }\end{array}$ \\
\hline
\end{tabular}


ISSN: 2394 - 0913, Volume-4 Issue-10, June 2020

\begin{tabular}{|c|c|c|c|c|c|c|c|c|c|c|c|c|}
\hline 2 & Polyroad & $\begin{array}{l}\text { Stabilising } \\
\text { binder for } \\
\text { rehabilitation } \\
\text { of granular } \\
\text { pavements } \\
\text { and new } \\
\text { pavement } \\
\text { construction }\end{array}$ & IDPSP & $\begin{array}{l}\text { Polyroad is a dry, } \\
\text { powdered polymer, mixed } \\
\text { with hydrated lime. Three } \\
\text { Polyroad products } \\
\text { identified: Polyroad } \\
\text { PR100; Polyroad PR11L; } \\
\text { and, Polyroad PR21L. } \\
\text { Polyroad PR11L and } \\
\text { Polyroad PR21L contain } \\
\text { hydrated lime, whereas } \\
\text { Polyroad } 100 \text { does not and } \\
\text { can be used alone, or to } \\
\text { form the base of the other } \\
\text { two Polyroad Products. } \\
\text { Lime will react with water } \\
\text { and raise the pH, which } \\
\text { may have a deleterious } \\
\text { effect on freshwater } \\
\text { organisms. }\end{array}$ & $\begin{array}{l}\text { No Data } \\
\text { Available }\end{array}$ & $\begin{array}{c}\text { No data } \\
\text { Available }\end{array}$ & $\begin{array}{l}\text { Polymer is } \\
\text { insoluble } \\
\text { but lime is } \\
\text { soluble in } \\
\text { water and } \\
\text { raises pH }\end{array}$ & $\begin{array}{l}\text { Persistent but } \\
\text { bioaccumulation } \\
\text { considered low }\end{array}$ & $\begin{array}{l}\text { Polymer } \\
\text { considered inert } \\
\text { once fully } \\
\text { reacted but will } \\
\text { have a raised } \\
\text { pH while } \\
\text { setting. }\end{array}$ & $\begin{array}{l}\text { Polyroad is } \\
\text { hydrophobic and } \\
\text { repels water. Until } \\
\text { reacted the presence } \\
\text { of lime may give } \\
\text { rise to } \\
\text { moderate/severe } \\
\text { irritation or burns. In } \\
\text { water, lime will } \\
\text { raise pH and may } \\
\text { have a deleterious } \\
\text { effect on freshwater } \\
\text { organisms until } \\
\text { reacted fully. }\end{array}$ & $\begin{array}{l}\text { Polymer, } \\
\text { hydrated lime } \\
\text { and typically } \\
\text { flyash, } \\
\text { including } \\
\text { aluminium } \\
\text { oxide and } \\
\text { amorphous } \\
\text { crystalline } \\
\text { silica. Polymer } \\
\text { encapsulates } \\
\text { flyash, making } \\
\text { it inert and not } \\
\text { reacting } \\
\text { chemically in } \\
\text { the stabilisation } \\
\text { process. } \\
\text { Hydrated lime } \\
\text { is added to the } \\
\text { polymer-coated } \\
\text { carrier to } \\
\text { flocculate and } \\
\text { prepare clay } \\
\text { particles for } \\
\text { adhesion to the } \\
\text { polymer }\end{array}$ & $\begin{array}{l}\text { Polymer is considered } \\
\text { inert but the presence } \\
\text { of lime gives rise to } \\
\text { safety concerns when } \\
\text { handling and PPE } \\
\text { must be worn. Avoid } \\
\text { contact with skin and } \\
\text { eyes. }\end{array}$ \\
\hline
\end{tabular}

Retrieval Number: J09860641020/2020@BEIESP DOI:10.35940/ijmh.J0986.0641020

Journal Website: www.ijmh.org
Published By:

Blue Eyes Intelligence Engineering \& Sciences Publication

(c) Copyright: All rights reserved.

and $\mathrm{Hum}$

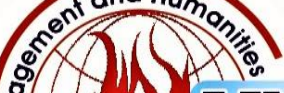

- (2)

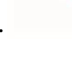

Exploring Innovation 


\begin{tabular}{|c|c|c|c|c|c|c|c|c|c|c|c|c|}
\hline 3 & Ecobond & $\begin{array}{l}\text { Used beneath } \\
\text { blacktop / } \\
\text { bituminous } \\
\text { seal to } \\
\text { improve } \\
\text { bearing } \\
\text { capacity of } \\
\text { base course } \\
\text { and lower } \\
\text { layers. } \\
\text { Improves } \\
\text { bitumen } \\
\text { performance. } \\
\text { Can be used } \\
\text { as wearing } \\
\text { course for } \\
\text { light loads. }\end{array}$ & $\begin{array}{l}\text { Synthetic } \\
\text { soluble } \\
\text { polymer. } \\
\text { Synthetic } \\
\text { resin } \\
\text { reinforced } \\
\text { bitumen } \\
\text { emulsion } \\
\text { (anionic) }\end{array}$ & $\begin{array}{l}\text { Four component mixture, } \\
\text { comprising an anionic } \\
\text { bitumen emulsion (EB4) } \\
\text { reinforced with Urea } \\
\text { (EB1), UFC (EB2) and a } \\
\text { proprietary activator } \\
\text { (EB3.) The chemicals } \\
\text { form a cross linked resin } \\
\text { that forms polymer fibres, } \\
\text { together with bitumen/soil } \\
\text { etc. to bind aggregates in } \\
\text { heavy to light duty roads. } \\
\text { Product is both sufficiently } \\
\text { strong and water resistant } \\
\text { to be used with/without a } \\
\text { bitumen seal }\end{array}$ & $\begin{array}{l}\text { No Data } \\
\text { Available }\end{array}$ & $\begin{array}{c}\text { No data } \\
\text { Available }\end{array}$ & $\begin{array}{l}\text { Does not } \\
\text { leach out } \\
\text { into the } \\
\text { environmen } \\
\text { t, as it is } \\
\text { water } \\
\text { insoluble } \\
\text { but remains } \\
\text { porous and } \\
\text { is mostly } \\
\text { bound to } \\
\text { other } \\
\text { particles. }\end{array}$ & $\begin{array}{l}\text { Will revert back } \\
\text { to carbon, oxygen, } \\
\text { hydrogen and } \\
\text { nitrogen after } \\
\text { centuries. }\end{array}$ & $\begin{array}{l}\text { Chemically } \\
\text { inert, once fully } \\
\text { reacted and will } \\
\text { not react easily } \\
\text { with any other } \\
\text { substances in } \\
\text { the soil to form } \\
\text { toxic } \\
\text { substances. }\end{array}$ & $\begin{array}{l}\text { Low when reacted. } \\
\text { Claims to be } \\
\text { insoluble and mostly } \\
\text { bound to other } \\
\text { particles }\end{array}$ & $\begin{array}{l}\text { Limestone, lime } \\
\text { and cationic } \\
\text { polymer }\end{array}$ & $\begin{array}{l}\text { EB2 component (urea } \\
\text { formaldehyde pre- } \\
\text { condensate) is largely } \\
\text { pre-reacted (for safety) } \\
\text { but does contain some } \\
\text { free formaldehyde. } \\
\text { Formaldehyde } \\
\text { emissions have a } \\
\text { strong, pungent odour } \\
\text { that can cause eye and } \\
\text { respiratory irritation in } \\
\text { high concentrations. } \\
\text { EB3 activator is a } \\
\text { weak organic acid. } \\
\text { EB4 is a bitumen } \\
\text { emulsion (anionic } \\
\text { stable grade), } \\
\text { containing } 60 \% \\
\text { bitumen particles } \\
\text { suspended in } 40 \% \\
\text { water by an emulsion } \\
\text { (like soap bubbles) } \\
\text { with alkaline pH } 11 . \\
\end{array}$ \\
\hline 4 & $\begin{array}{l}\text { Polyroads_S } \\
\text { oilTech } \\
\text { Polymers }\end{array}$ & $\begin{array}{l}\text { Road } \\
\text { stabilization } \\
\text { of base and } \\
\text { sub-base } \\
\text { strength and } \\
\text { dust } \\
\text { suppression. } \\
\text { Suitable for } \\
\text { light top } \\
\text { course use. }\end{array}$ & IDPSP & $\begin{array}{l}\text { Three-part mix comprising } \\
\text { limestone, hydrated lime } \\
\text { and non-hazardous, } \\
\text { cationic polymer. } \\
\text { Appearance is a light grey, } \\
\text { fine grained, powdery solid } \\
\text { mixture, negligible } \\
\text { solubility in water and } \\
\text { contains respirable fines }<7 \\
\text { microns diameter. }\end{array}$ & $\begin{array}{l}>100 \mathrm{mg} / \mathrm{l} \text { trout. } \\
>1000 \mathrm{mg} / \mathrm{l} \\
\text { daphnia }\end{array}$ & $\begin{array}{c}\text { No data } \\
\text { available }\end{array}$ & Resistant & $\begin{array}{l}\text { Yes. Stated as } \\
\text { low level of } \\
\text { bioaccumulation }\end{array}$ & $\begin{array}{l}\text { No Data } \\
\text { Available }\end{array}$ & $\begin{array}{l}\text { SoilTech Mk III has } \\
\text { no hazard } \\
\text { classification } \\
\text { according to } \\
\text { 88/379/EEC. }\end{array}$ & $\begin{array}{l}\text { Three-part mix, } \\
\text { comprising } \\
\text { limestone, } \\
\text { hydrated lime } \\
\text { and a non- } \\
\text { hazardous, } \\
\text { cationic } \\
\text { polymer. }\end{array}$ & $\begin{array}{l}\text { Reacts with aluminium } \\
\text { / zinc producing } \\
\text { flammable, explosive } \\
\text { hydrogen gas. Avoid } \\
\text { strong acids, acid } \\
\text { chlorides, acid } \\
\text { anhydrides and } \\
\text { chloroformates. } \\
\text { Causes burns., risk of } \\
\text { serious damage to eyes } \\
\text { and do not breathe } \\
\text { dust. }\end{array}$ \\
\hline
\end{tabular}

Retrieval Number: J09860641020/2020@BEIESP DOI:10.35940/ijmh.J0986.0641020

Journal Website: www.ijmh.org
Published By:

Blue Eyes Intelligence Engineerin

(c) Copyright: All rights reserved. and Hum

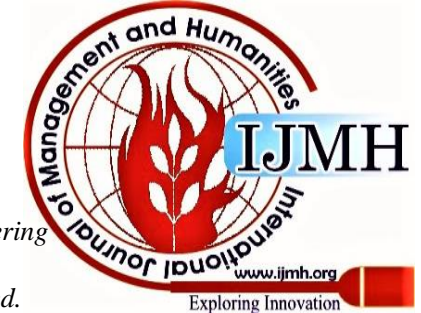


ISSN: 2394 - 0913, Volume-4 Issue-10, June 2020

\begin{tabular}{|c|c|c|c|c|c|c|c|c|c|c|c|c|}
\hline 5 & $\begin{array}{l}\text { Renolith } \\
\text { WSS }\end{array}$ & $\begin{array}{l}\text { Used on gravel } \\
\text { roads and } \\
\text { stabilised in- } \\
\text { situ road } \\
\text { layers with a } \\
\text { sand seal or } \\
\text { heavier } \\
\text { surfacing. }\end{array}$ & $\begin{array}{l}\text { Synthetic } \\
\text { soluble } \\
\text { polymer }\end{array}$ & $\begin{array}{l}\text { Applied as a liquid. When } \\
\text { mixed with cement and } \\
\text { local soils, will form a } \\
\text { stable concrete. }\end{array}$ & $\begin{array}{l}\text { No Data } \\
\text { Available }\end{array}$ & $\begin{array}{c}\text { No data } \\
\text { available }\end{array}$ & $\begin{array}{l}\text { insoluble } \\
\text { once } \\
\text { set/reacted }\end{array}$ & $\begin{array}{l}\text { No data available. } \\
\text { Letter from Dr } \\
\text { James Rowe, } \\
\text { Scientific } \\
\text { Director of } \\
\text { Technical } \\
\text { Consultancy } \\
\text { Services Ltd } \\
\text { (Australia) March } \\
2000 \text { confirms the } \\
\text { MSDS has been } \\
\text { reviewed and } \\
\text { Renolith is } \\
\text { considered non- } \\
\text { toxic to the } \\
\text { environment. }\end{array}$ & $\begin{array}{l}\text { Chemically inert } \\
\text { once reacted. } \\
\text { While unreacted, } \\
\text { not to be } \\
\text { discharge to } \\
\text { sewer or } \\
\text { waterways, as it } \\
\text { increases the } \\
\text { hardness of } \\
\text { water. Although } \\
\text { inorganic } \\
\text { chloride ions are } \\
\text { not normally } \\
\text { considered toxic, } \\
\text { they can exist in } \\
\text { effluents at } \\
\text { acutely toxic } \\
\text { levels (chloride } \\
>3000 \text { mg/l). } \\
\text { Resulting salinity } \\
\text { can exceed the } \\
\text { tolerances of } \\
\text { most freshwater } \\
\text { organisms. }\end{array}$ & $\begin{array}{l}\text { Low. Claimed that } \\
\text { hydrated calcium } \\
\text { chloride chemically } \\
\text { binds with cement } \\
\text { and soils to perform } \\
\text { a stable compound } \\
\text { and leachability } \\
\text { considered low. } \\
\text { Due to calcium } \\
\text { chloride, may harm } \\
\text { local water courses } \\
\text { and lead to adverse } \\
\text { effects on aquatic } \\
\text { organisms at high } \\
\text { concentrations in } \\
\text { fresh water. The } \\
\text { toxicity of chloride } \\
\text { salts depends on the } \\
\text { counter-ion (cation) } \\
\text { present; that of } \\
\text { chloride itself is } \\
\text { unknown. A harmful } \\
\text { effect of aquatic } \\
\text { organisms is only to } \\
\text { be expected at high } \\
\text { concentrations. } \\
\text { [Merck] }\end{array}$ & $\begin{array}{l}\text { Little data } \\
\text { available but the } \\
\text { bioaccumulatio } \\
\text { n potential is } \\
\text { considered low, } \\
\text { based upon the } \\
\text { presence of } \\
\text { hydrated } \\
\text { calcium } \\
\text { chloride. } \\
\text { Contains acrylic } \\
\text { resin }<5 \% \text {; } \\
\text { calcium salt } \\
<8 \% \text {; mineral } \\
\text { oil }<1 \% \text {, } \\
\text { "cellulose" } \\
<2 \% \text {; water to } \\
100 \% \text {. } \\
\text { Alternatively, } \\
\text { composition } \\
\text { given as } \\
\text { calcium } \\
\text { chloride, } \\
\text { hydrated } 10- \\
30 \% \text {; acrylic co- } \\
\text { polymer latex } \\
10-30 \% \text {; water } \\
30-60 \%\end{array}$ & $\begin{array}{l}\text { Standard health and } \\
\text { hygiene measures. } \\
\text { Incidental exposure to } \\
\text { inorganic chloride may } \\
\text { occur in occupational } \\
\text { settings where } \\
\text { chemicals } \\
\text { management policies } \\
\text { are improperly } \\
\text { applied. Chloride } \\
\text { toxicity has not been } \\
\text { observed in humans } \\
\text { except in the special } \\
\text { case of impaired } \\
\text { sodium. }\end{array}$ \\
\hline 6 & $\begin{array}{l}\text { DirtGlue } \\
\text { industrial } \\
\text { polymer } \\
\text { (Dgip) }\end{array}$ & $\begin{array}{l}\text { Stabilisation } \\
\text { of high } \\
\text { plasticity soils }\end{array}$ & $\begin{array}{l}\text { Synthetic } \\
\text { soluble } \\
\text { polymer }\end{array}$ & $\begin{array}{l}\text { May be mixed with } \\
\text { PolyCure/TerraDry. } \\
\text { PolyCure is an anhydrous } \\
\text { mix of inorganic mineral } \\
\text { compounds and acrylate- } \\
\text { based, fine, granular } \\
\text { powdered polymers. }\end{array}$ & $\begin{array}{l}\text { No Data } \\
\text { Available. Not } \\
\text { considered to } \\
\text { have a } \\
\text { toxicological } \\
\text { impact on plants } \\
\text { or animals. }\end{array}$ & $\begin{array}{c}\text { No data } \\
\text { available }\end{array}$ & $\begin{array}{l}\text { Soluble if } \\
\text { entering the } \\
\text { water } \\
\text { environmen } \\
\text { t before } \\
\text { setting/curin } \\
\text { gTerraDry } \\
\text { may have a } \\
\text { short-term } \\
\text { deleterious } \\
\text { effect. }\end{array}$ & $\begin{array}{l}\text { Unknown. } \\
\text { DirtGlue } \\
\text { Polymer, } \\
\text { DirtGlue } \\
\text { Industrial } \\
\text { Polymer and } \\
\text { PolyCure are not } \\
\text { considered } \\
\text { harmful to the } \\
\text { environment. }\end{array}$ & \begin{tabular}{l|} 
Chemically \\
inert, once \\
reacted. Non- \\
toxic and \\
approved under \\
international \\
recognised \\
materials \\
environmental \\
authority \\
standards and/or \\
registration. \\
Has no \\
Hazchem or UN \\
number.
\end{tabular} & $\begin{array}{l}\text { Unknown. MSDS } \\
\text { for DirtGlue } \\
\text { polymer emulsion } \\
\text { and DirtGlue } \\
\text { Industrial Polymer } \\
\text { indicates no } \\
\text { significant } \\
\text { environmental } \\
\text { hazards. }\end{array}$ & $\begin{array}{l}\text { Water-based, } \\
\text { heavy duty } \\
\text { acrylic powder } \\
\text { formulation }\end{array}$ & \\
\hline
\end{tabular}

Retrieval Number: J09860641020/2020@BEIESP DOI:10.35940/ijmh.J0986.0641020

Journal Website: www.ijmh.org
Published By:

Blue Eyes Intelligence Engineering (c) Copyright: All rights reserved. and $\mathrm{Hum}$

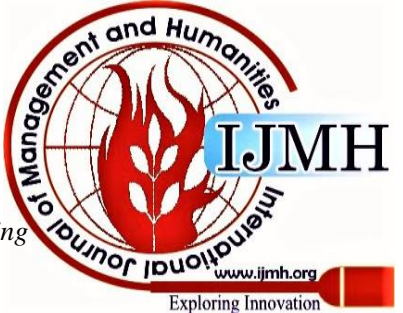




\begin{tabular}{|c|c|c|c|c|c|c|c|c|c|c|c|c|}
\hline 7 & $\begin{array}{l}\text { DirtGlue: } \\
\text { TerraDura } \\
\text { and } \\
\text { TerraDry }\end{array}$ & $\begin{array}{l}\text { Road base } \\
\text { stabilizer, } \\
\text { subgrade } \\
\text { waterproofing } \\
\text { agent and } \\
\text { polymer } \\
\text { pavement } \\
\text { additive to } \\
\text { increase bond } \\
\text { and water } \\
\text { resistance in } \\
\text { the surface } \\
\text { layer. }\end{array}$ & $\begin{array}{l}\text { Synthetic } \\
\text { soluble } \\
\text { polymer }\end{array}$ & $\begin{array}{l}\text { Liquid polymer } \\
\text { concentrates. Polymers } \\
\text { are non-toxic, non- } \\
\text { flammable, non- } \\
\text { carcinogenic and use no } \\
\text { solvents to contaminate } \\
\text { land and water. }\end{array}$ & $\begin{array}{l}\text { No data } \\
\text { available }\end{array}$ & $\begin{array}{c}\text { No data } \\
\text { available }\end{array}$ & $\begin{array}{l}\text { Soluble in } \\
\text { water. Non- } \\
\text { hazardous } \\
\text { to plant, } \\
\text { animal and } \\
\text { marine life } \\
\text { and } \\
\text { impervious } \\
\text { to water } \\
\text { after curing. }\end{array}$ & $\begin{array}{l}\text { No data available. } \\
\text { Essentially non- } \\
\text { hazardous once } \\
\text { cured. }\end{array}$ & $\begin{array}{l}\text { Formaldehyde } \\
\text { generated under } \\
\text { acidic } \\
\text { conditions. } \\
\text { Thermal } \\
\text { decomposition } \\
\text { may result in } \\
\text { acrylic } \\
\text { monomers. }\end{array}$ & $\begin{array}{l}\text { Low. Once cured } \\
\text { no chemical, surface } \\
\text { wash-off or toxicity } \\
\text { threat to land or } \\
\text { adjacent waterways. } \\
\text { In initial liquid } \\
\text { form, care must be } \\
\text { given when applying } \\
\text { in wetlands or near } \\
\text { surface water as it } \\
\text { will raise the pH and } \\
\text { may have } \\
\text { deleterious effect on } \\
\text { fresh water } \\
\text { organisms. Care } \\
\text { must be taken on } \\
\text { application to ensure } \\
\text { non product enters } \\
\text { the water } \\
\text { environment, } \\
\text { especially, when } \\
\text { using TerraDry. }\end{array}$ & $\begin{array}{l}\text { TerraDry is an } \\
\text { organo-silane, } \\
\text { blend of sodium } \\
\text { siliconate and } \\
\text { potassium } \\
\text { siliconate in } \\
\text { water. }\end{array}$ & $\begin{array}{l}\text { TerraDry is a } \\
\text { corrosive substance } \\
\text { and will cause caustic } \\
\text { burns. }\end{array}$ \\
\hline 8 & $\begin{array}{l}\text { Silt Stop } \\
700 \text { Series }\end{array}$ & $\begin{array}{l}\text { Dust } \\
\text { suppression } \\
\text { and erosion } \\
\text { control }\end{array}$ & $\begin{array}{l}\text { Synthetic } \\
\text { soluble } \\
\text { polymer }\end{array}$ & $\begin{array}{l}\text { Anionic polyacrylamide } \\
\text { co-polymer emulsion } \\
\text { binding agent, comprising } \\
\text { a range of anionic, water- } \\
\text { soluble co-polymer gels } \\
\text { and anionic, water-soluble, } \\
\text { co-polymer powders. }\end{array}$ & $\begin{array}{l}\text { Generally } \\
>420 \mathrm{ppm} \text {. }\end{array}$ & $\begin{array}{l}\text { Generally } \\
>500 p p m\end{array}$ & $\begin{array}{l}\text { Soluble as } \\
\text { gel and } \\
\text { powder } \\
\text { until cured }\end{array}$ & $\begin{array}{l}\text { Both gels and the } \\
\text { powders are not } \\
\text { readily } \\
\text { biodegradable } \\
\text { and will not } \\
\text { readily } \\
\text { bioaccumulate. } \\
\text { Essentially non- } \\
\text { hazardous. }\end{array}$ & $\begin{array}{l}\text { Stable. Review } \\
\text { of the MSDS } \\
\text { for gels and } \\
\text { powders } \\
\text { indicates they } \\
\text { are non-toxic } \\
\text { and non- } \\
\text { reactive. }\end{array}$ & $\begin{array}{l}\text { Low once product } \\
\text { has set. Care should } \\
\text { be given on } \\
\text { application in } \\
\text { wetlands or near } \\
\text { water to prevent the } \\
\text { unreacted product } \\
\text { entering water } \\
\text { courses. }\end{array}$ & $\begin{array}{l}\text { Polyacrylamide } \\
\text { co-polymer, } \\
\text { water soluble } \\
\text { gels or anionic, } \\
\text { water-soluble } \\
\text { co-polymer } \\
\text { powders. }\end{array}$ & $\begin{array}{l}\text { Prevent inhalation of } \\
\text { the powder, use } \\
\text { adequate dust mask }\end{array}$ \\
\hline 9 & SoilTac & $\begin{array}{l}\text { Dust } \\
\text { suppression } \\
\text { and erosion } \\
\text { control }\end{array}$ & $\begin{array}{l}\text { Synthetic } \\
\text { soluble } \\
\text { polymer }\end{array}$ & $\begin{array}{l}\text { Vinyl co-polymer } \\
\text { emulsion, designed to } \\
\text { penetrate the soil / } \\
\text { aggregate layer and bind } \\
\text { together the soil / } \\
\text { aggregate particles. } \\
\text { Applied as liquid emulsion. }\end{array}$ & $\begin{array}{l}\text { 96-hour LC50 } \\
>1,000 \mathrm{mg} / \mathrm{l}\end{array}$ & $\begin{array}{c}\text { 96-hour } \\
\text { LC50 } \\
>1,000 \mathrm{mg} / \mathrm{l}\end{array}$ & Emulsion & $\begin{array}{l}\text { Biodegradable. } \\
\text { Essentially non- } \\
\text { hazardous. }\end{array}$ & Stable & $\begin{array}{l}\text { Low - designed to } \\
\text { penetrate surface } \\
\text { layers and bind to } \\
\text { soil particles. Once } \\
\text { cured no leaching } \\
\text { should occur. Care } \\
\text { required when } \\
\text { applying in wetlands } \\
\text { and near surface } \\
\text { waters. }\end{array}$ & $\begin{array}{l}\text { Vinyl co- } \\
\text { polymer } \\
\text { emulsion }\end{array}$ & $\begin{array}{l}\text { Use only in well- } \\
\text { ventilated areas. } \\
\text { Avoid contact with } \\
\text { eyes., breathing } \\
\text { vapours and avoid } \\
\text { prolonged or repeated } \\
\text { contact with skin. } \\
\text { Wash hands } \\
\text { thoroughly after } \\
\text { handling and before } \\
\text { eating or drinking }\end{array}$ \\
\hline
\end{tabular}

Retrieval Number: J09860641020/2020@BEIESP DOI:10.35940/ijmh.J0986.0641020

Journal Website: www.ijmh.org
Published By:

Blue Eyes Intelligence Engineerin

(c) Copyright: All rights reserved. and $\mathrm{Hum}$

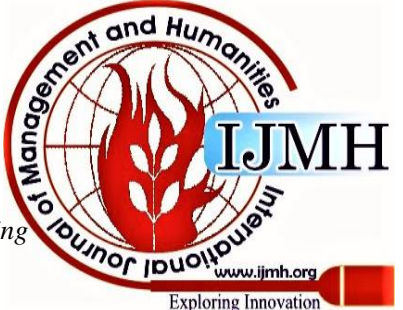


International Journal of Management and Humanities (IJMH)

ISSN: 2394 - 0913, Volume-4 Issue-10, June 2020

\begin{tabular}{|c|c|c|c|c|c|c|c|c|c|c|c|c|}
\hline 10 & Soil Sement & 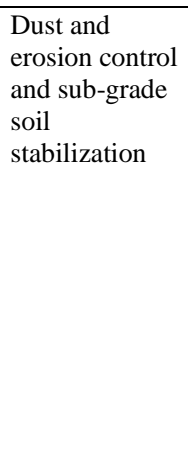 & $\begin{array}{l}\text { Synthetic } \\
\text { soluble } \\
\text { polymer }\end{array}$ & $\begin{array}{l}\text { Acrylic vinyl acetate } \\
\text { polymer emulsion that } \\
\text { binds soil/aggregate } \\
\text { particles together with a } \\
\text { molecular mesh. }\end{array}$ & 3,483ppm & $>1,000$ & $\begin{array}{l}\text { Forms } \\
\text { emulsion }\end{array}$ & $\begin{array}{l}\text { Not known. } \\
\text { Product is stable } \\
\text { and non- } \\
\text { hazardous. }\end{array}$ & Stable & Not known. & $\begin{array}{l}\text { Aqueous acrylic } \\
\text { vinyl acetate } \\
\text { polymer } \\
\text { emulsion. Does } \\
\text { not contain any } \\
\text { detectable } \\
\text { polycyclic } \\
\text { organic matter } \\
\text { (POM), } \\
\text { including } \\
\text { polynuclear } \\
\text { aromatic } \\
\text { hydrocarbons } \\
\text { (PAH). }\end{array}$ & $\begin{array}{l}\text { Standard eye } \\
\text { protection }\end{array}$ \\
\hline 11 & Sasbind & $\begin{array}{l}\text { Suitable for } \\
\text { binding/stabili } \\
\text { sation of } \\
\text { layers in all } \\
\text { types of road } \\
\text { construction. }\end{array}$ & $\begin{array}{l}\text { Synthetic } \\
\text { soluble } \\
\text { polymer }\end{array}$ & $\begin{array}{l}\text { Provides strong gluing and } \\
\text { waterproofing action on } \\
\text { soil particles and is suitable } \\
\text { for application to a wide } \\
\text { variety of soil types, } \\
\text { improving the wet weather } \\
\text { performance of soils and } \\
\text { gravel roads }\end{array}$ & $\begin{array}{l}\text { No Data } \\
\text { Available }\end{array}$ & $\begin{array}{l}\text { No Data } \\
\text { Available }\end{array}$ & Not known. & $\begin{array}{l}\text { Stated as having } \\
\text { no long-term } \\
\text { adverse impact on } \\
\text { the environment, } \\
\text { is non-toxic and } \\
\text { non-hazardous } \\
\text { and is safe to } \\
\text { handle. Company } \\
\text { not contactable } \\
\text { for MSDS. }\end{array}$ & $\begin{array}{l}\text { No Data } \\
\text { Available }\end{array}$ & Not known. & $\begin{array}{l}\text { Water based, } \\
\text { acrylic polymer } \\
\text { emulsion }\end{array}$ & Nothing specific \\
\hline 12 & $\begin{array}{l}\text { PennzSuppr } \\
\text { ess D }\end{array}$ & $\begin{array}{l}\text { Used as dust } \\
\text { suppressant } \\
\text { and soil } \\
\text { stabilizer }\end{array}$ & $\begin{array}{l}\text { Synthetic } \\
\text { soluble } \\
\text { polymer }\end{array}$ & $\begin{array}{l}\text { Concentrated paraffin resin } \\
\text { solution with ionic and } \\
\text { non-ionic surfactants. } \\
\text { Diluted with water until } \\
\text { required concentration } \\
\text { produced. }\end{array}$ & $\begin{array}{l}\text { No Data } \\
\text { Available }\end{array}$ & $\begin{array}{l}>510 \mathrm{mg} / \mathrm{l} \\
\text { Fathead } \\
\text { minnow; } \\
\text { 913mg/l } \\
\text { Rainbow } \\
\text { trout }\end{array}$ & $\begin{array}{l}\text { Forms } \\
\text { emulsion. } \\
\text { When still a } \\
\text { liquid } \\
\text { product, } \\
\text { should be } \\
\text { used with } \\
\text { care near } \\
\text { wetlands or } \\
\text { surface } \\
\text { waters. }\end{array}$ & $\begin{array}{l}\text { Not known. } \\
\text { Classified as } \\
\text { "non-hazardous," } \\
\text { "non-toxic," and } \\
\text { "non- } \\
\text { carcinogenic" by } \\
\text { Federal US } \\
\text { guidelines and is } \\
\text { considered non- } \\
\text { toxic to aquatic } \\
\text { life. }\end{array}$ & $\begin{array}{l}\text { Stable under } \\
\text { normal } \\
\text { conditions, but } \\
\text { avoid strong } \\
\text { acids and strong } \\
\text { oxidising } \\
\text { materials }\end{array}$ & $\begin{array}{l}\text { Low once product } \\
\text { has cured. Care } \\
\text { needed on } \\
\text { application in } \\
\text { wetlands or near } \\
\text { watercourses, due to } \\
\text { potential to cause } \\
\text { oil-like pollution in } \\
\text { surface waters. }\end{array}$ & $\begin{array}{l}\text { Paraffin resin in } \\
\text { solution with } \\
\text { water soluble, } \\
\text { anionic and } \\
\text { non-ionic } \\
\text { surfactants. }\end{array}$ & Nothing specific \\
\hline 13 & $\begin{array}{l}\text { Tembind } \\
\text { Lignosulfon } \\
\text { ate Grade } \\
\text { A-002 }\end{array}$ & $\begin{array}{l}\text { Used as dust } \\
\text { suppressant } \\
\text { and road } \\
\text { stabilizer }\end{array}$ & $\begin{array}{l}\text { Organic. } \\
\text { Lignosulp } \\
\text { honate }\end{array}$ & $\begin{array}{l}\text { Lignosulphonate polymer } \\
\text { that acts as a binding agent } \\
\text { for soil/aggregate particles } \\
\text { to ensure better } \\
\text { compaction and } \\
\text { stabilisation of road } \\
\text { surfaces. }\end{array}$ & $\begin{array}{l}\text { No Data } \\
\text { Available }\end{array}$ & $\begin{array}{l}\text { No Data } \\
\text { Available }\end{array}$ & $\begin{array}{l}\text { Not soluble } \\
\text { but an } \\
\text { emulsion }\end{array}$ & $\begin{array}{l}\text { Biodegradable } \\
\text { over time. } \\
\text { Essentially non- } \\
\text { hazardous. }\end{array}$ & $\begin{array}{l}\text { No Data } \\
\text { Available }\end{array}$ & $\begin{array}{l}\text { No leaching } \\
\text { problems once set. } \\
\text { Poor application in } \\
\text { wetlands/near } \\
\text { surface waters may } \\
\text { cause contamination } \\
\text { of water courses and } \\
\text { short-term elevated } \\
\text { BOD /COD but no } \\
\text { permanent effect. }\end{array}$ & $\begin{array}{l}\text { Ammonium } \\
\text { lignosulphonate }\end{array}$ & $\begin{array}{l}\text { Standard PPE for eye } \\
\text { protection and gloves } \\
\text { for skin contact }\end{array}$ \\
\hline
\end{tabular}

Retrieval Number: J09860641020/2020@BEIESP DOI:10.35940/ijmh.J0986.0641020

Journal Website: www.ijmh.org
Published By:

Blue Eyes Intelligence Engineering \& Sciences Publication

(c) Copyright: All rights reserved. and Hum

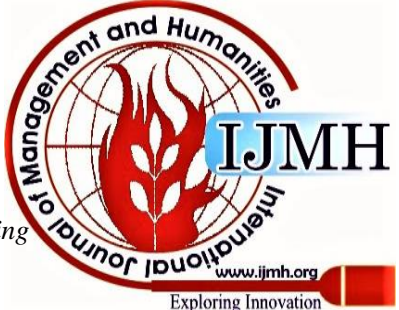




\begin{tabular}{|c|c|c|c|c|c|c|c|c|c|c|c|c|}
\hline 14 & Dustex & $\begin{array}{l}\text { Used as dust } \\
\text { suppressant } \\
\text { for road } \\
\text { surfaces. }\end{array}$ & $\begin{array}{l}\text { Organic. } \\
\text { Lignosulp } \\
\text { honate }\end{array}$ & $\begin{array}{l}\text { Calcium lignosulphonate } \\
\text { liquid, act as binding agent } \\
\text { for soil and aggregate } \\
\text { particles. }\end{array}$ & $\begin{array}{l}\text { According to } \\
\text { OECD Method } \\
\text { No. } 203 \text { this } \\
\text { product is } \\
\text { classified as not } \\
\text { fish toxic. }\end{array}$ & $\begin{array}{c}\text { No Data } \\
\text { Available }\end{array}$ & Soluble & $\begin{array}{l}\text { According to } \\
\text { OECD Method } \\
\text { No. 302B, this } \\
\text { product classified } \\
\text { as inherently } \\
\text { biodegradable } \\
\text { and non- } \\
\text { hazardous }\end{array}$ & $\begin{array}{l}\text { No Data } \\
\text { Available }\end{array}$ & $\begin{array}{l}\text { Low once cured, } \\
\text { becoming } \\
\text { impermeable. As a } \\
\text { liquid care must be } \\
\text { given when applying } \\
\text { in wetlands or near } \\
\text { surface waters. }\end{array}$ & \begin{tabular}{|l|} 
Calcium \\
lignosulphonate
\end{tabular} & $\begin{array}{l}\text { Standard PPE for eye } \\
\text { protection and gloves } \\
\text { for skin contact. } \\
\text { Dustex is slightly } \\
\text { acidic with pH of } 5.4 \pm \\
\text { 3.0. }\end{array}$ \\
\hline 15 & $\begin{array}{l}\text { LFPP Spent } \\
\text { Liquor } 2\end{array}$ & $\begin{array}{l}\text { Stabilisation } \\
\text { of road } \\
\text { surfaces and } \\
\text { used as a dust } \\
\text { suppressant } \\
\text { for road } \\
\text { surfaces }\end{array}$ & $\begin{array}{l}\text { Organic. } \\
\text { Lignosulp } \\
\text { honate }\end{array}$ & $\begin{array}{l}\text { Lignosulphonates act as } \\
\text { binding agents to bind soil } \\
\text { and aggregate particles } \\
\text { together to ensure better } \\
\text { compaction and become } \\
\text { impermeable after curing. }\end{array}$ & & $\begin{array}{l}\text { No Data } \\
\text { Available }\end{array}$ & $\begin{array}{l}\text { Not soluble } \\
\text { but an } \\
\text { emulsion }\end{array}$ & $\begin{array}{l}\text { Biodegradable } \\
\text { over time. } \\
\text { Essentially non- } \\
\text { hazardous }\end{array}$ & $\begin{array}{l}\text { No Data } \\
\text { Available }\end{array}$ & $\begin{array}{l}\text { Once set should } \\
\text { have no leaching } \\
\text { problems. Poor } \\
\text { application in } \\
\text { wetlands or near } \\
\text { surface waters may } \\
\text { produce } \\
\text { contamination of } \\
\text { water courses. If this } \\
\text { occurs may give rise } \\
\text { to short-term } \\
\text { elevated BOD or } \\
\text { COD but no } \\
\text { permanent effect. }\end{array}$ & & $\begin{array}{l}\text { Standard PPE for eye } \\
\text { protection and gloves } \\
\text { for skin contact }\end{array}$ \\
\hline 16 & ENTAC & $\begin{array}{l}\text { Road dust } \\
\text { suppressant }\end{array}$ & $\begin{array}{l}\text { Synthetic } \\
\text { soluble } \\
\text { polymer }\end{array}$ & $\begin{array}{l}\text { Tall Oil Pitch (T.O.P) is a } \\
\text { pitch-in-water emulsion }\end{array}$ & $\begin{array}{l}\text { Non-lethal to } \\
\text { aquatic } \\
\text { organisms, } \\
\text { Daphnia } \\
\text { Magna, } \\
\text { Rainbow Trout. }\end{array}$ & $\begin{array}{l}\text { No Data } \\
\text { Available }\end{array}$ & $\begin{array}{l}\text { Once } \\
\text { applied and } \\
\text { cured } \\
\text { unlikely to } \\
\text { cause any } \\
\text { leaching or } \\
\text { environmen } \\
\text { tal } \\
\text { concerns. }\end{array}$ & $\begin{array}{l}\text { Natural } \\
\text { decomposition } \\
\text { occurs over a } \\
\text { long time }(>60 \% \\
\text { biodegradation in } \\
\text { 28days. } \\
\text { Degradation } \\
\text { products } \mathrm{CO}, \mathrm{CO}_{2} \\
\text { and water } \\
\end{array}$ & $\begin{array}{l}\text { No Data } \\
\text { Available }\end{array}$ & $\begin{array}{l}\text { Insoluble in water } \\
\text { and extremely } \\
\text { viscous in its natural } \\
\text { state. Stated as } \\
\text { having "no negative } \\
\text { environmental } \\
\text { impacts". }\end{array}$ & $\begin{array}{l}\text { Pitch-in-water } \\
\text { emulsion. Must } \\
\text { be emulsified to } \\
\text { facilitate its } \\
\text { handling and } \\
\text { usage. }\end{array}$ & Nothing specific \\
\hline
\end{tabular}


International Journal of Management and Humanities (IJMH)

ISSN: 2394 - 0913, Volume-4 Issue-10, June 2020

\begin{tabular}{|c|c|c|c|c|c|c|c|c|c|c|c|c|}
\hline 17 & $\begin{array}{l}\text { Earthbind } \\
100\end{array}$ & $\begin{array}{l}\text { Road dust } \\
\text { suppressant }\end{array}$ & $\begin{array}{l}\text { Synthetic } \\
\text { soluble } \\
\text { polymer }\end{array}$ & $\begin{array}{l}\text { Bituminous modified, } \\
\text { bitumen/water emulsion. } \\
\text { Product contains } 40-60 \% \\
\text { bitumen as an emulsion. }\end{array}$ & $\begin{array}{l}\text { Rainbow trout } \\
>5,000 \mathrm{ppm}\end{array}$ & $\begin{array}{l}\text { No Data } \\
\text { Available }\end{array}$ & $\begin{array}{l}\text { Once } \\
\text { applied and } \\
\text { cured } \\
\text { unlikely to } \\
\text { cause any } \\
\text { leaching or } \\
\text { environmen } \\
\text { tal } \\
\text { concerns. }\end{array}$ & $\begin{array}{l}\text { Persistent. } \\
\text { Website claims it } \\
\text { is non-flammable } \\
\text { and a non- } \\
\text { hazardous waste, } \\
\text { not considered } \\
\text { harmful to } \\
\text { aquatic and } \\
\text { mammal life or } \\
\text { carcinogenic. } \\
\text { Bitumen contains } \\
\text { carcinogenic } \\
\text { components and } \\
\text { the dermal } \\
\text { carcinogenicity of } \\
\text { testing bitumen } \\
\text { on mice showed } \\
\text { tumours arising } \\
\text { with a frequency } \\
\text { significantly } \\
\text { different from the } \\
\text { control study. No } \\
\text { data for } \\
\text { teratological } \\
\text { potential. }\end{array}$ & $\begin{array}{l}\text { No data } \\
\text { available. } \\
\text { Bitumen has } \\
\text { given negative } \\
\text { or marginally } \\
\text { positive } \\
\text { findings in most } \\
\text { mutagenicity } \\
\text { assays } \\
\text { conducted. }\end{array}$ & $\begin{array}{l}\text { Once set should not } \\
\text { have leachability } \\
\text { problems. Claims it } \\
\text { is not considered } \\
\text { harmful to aquatic } \\
\text { and mammal life } \\
\text { and claims not } \\
\text { considered to be } \\
\text { carcinogenic. Care } \\
\text { must be taken when } \\
\text { applying the liquid } \\
\text { emulsion in } \\
\text { wetland/water rich } \\
\text { areas to ensure } \\
\text { contamination of } \\
\text { water does not } \\
\text { occur. }\end{array}$ & $\begin{array}{l}40 \% \text { and } 60 \% \\
\text { bitumen } \\
\text { emulsion. }\end{array}$ & Nothing specific \\
\hline 18 & Iss2500 & $\begin{array}{l}\text { Suitable for } \\
\text { construction of } \\
\text { sealed } \\
\text { pavement } \\
\text { structures and } \\
\text { improvement } \\
\text { in } \\
\text { performance } \\
\text { of un-surfaced } \\
\text { roadways }\end{array}$ & $\begin{array}{l}\text { Ionic. } \\
\text { Oily, dark- } \\
\text { coloured } \\
\text { liquid, } \\
\text { miscible } \\
\text { with water }\end{array}$ & $\begin{array}{l}\text { Electrochemical clay soil } \\
\text { stabilizer suitable for } \\
\text { improving marginal or } \\
\text { substandard materials or } \\
\text { soils for use in the } \\
\text { construction of roads. . }\end{array}$ & $\begin{array}{l}\text { Once } \mathrm{pH} \\
\text { adjusted to the } \\
\text { range of } 7-8 \text {, all } \\
\text { bar one test } \\
\text { sample had } \\
100 \% \text { survival } \\
\text { for } D \text {. pulex and } \\
P \text {. reticulata, } \\
\text { indicating the } \\
\text { chemical } \\
\text { constituents are } \\
\text { not toxic }\end{array}$ & $\begin{array}{l}\text { No Data } \\
\text { Available }\end{array}$ & Soluble & $\begin{array}{l}\text { Unknown. } \\
\text { Product test data } \\
\text { claims it is } \\
\text { environmentally } \\
\text { safe and if } \\
\text { handled properly } \\
\text { should not pose } \\
\text { any adverse } \\
\text { impact on the } \\
\text { environment }\end{array}$ & $\begin{array}{l}\text { Once cured, } \\
\text { inert }\end{array}$ & $\begin{array}{l}\text { Low, once cured. } \\
\text { Care must be given } \\
\text { when applying in } \\
\text { wetlands or near } \\
\text { surface water due to } \\
\text { its acidic nature, will } \\
\text { lower pH in } \\
\text { freshwater. Will } \\
\text { have temporary } \\
\text { ecological harm but } \\
\text { no permanent effect. }\end{array}$ & $\begin{array}{l}\text { Hazardous. } \\
\text { Sulphonated } \\
\text { petroleum } \\
\text { products, } \\
\text { derived from } \\
\text { combined } \\
\text { organic sulphur } \\
\text { and buffered } \\
\text { acids combined } \\
\text { as bisulphates }\end{array}$ & $\begin{array}{l}\mathrm{pH}<2 \text { and can cause } \\
\text { acid burns. }\end{array}$ \\
\hline 19 & $\begin{array}{l}\text { Con- } \\
\text { Aid/CBR } \\
\text { PLUS }\end{array}$ & $\begin{array}{l}\text { Helps reduce } \\
\text { pavement } \\
\text { thickness and } \\
\text { is suitable for } \\
\text { light traffic } \\
\text { use }\end{array}$ & Ionic & $\begin{array}{l}\text { Water-soluble, anionic } \\
\text { compound with surface- } \\
\text { active properties, from a } \\
\text { blend of synthetic chemical } \\
\text { products, comprising } \\
\text { surfactant and sulphonic } \\
\text { acid derivatives, as an } \\
\text { organic acid solution in } \\
\text { water. Chemical Formula: } \\
\mathrm{R} \text { - SO3H, where R = } \\
\text { hydrocarbon. }\end{array}$ & $\begin{array}{l}\text { No Data } \\
\text { Available }\end{array}$ & $\begin{array}{c}\text { Not toxic at } \\
1-3 \mathrm{mg} / \mathrm{l}\end{array}$ & Soluble & $\begin{array}{l}\text { Yes. Claimed } \\
\text { non-toxic and } \\
\text { environmentally } \\
\text { friendly }\end{array}$ & $\begin{array}{l}\text { No Data } \\
\text { Available }\end{array}$ & $\begin{array}{l}\text { Leaching treated soil } \\
\text { samples showed no } \\
\text { toxicity to Rainbow } \\
\text { trout, Daphnia } \\
\text { Magna \& Microtox } \\
\text { at the concentration } \\
\text { of CBR PLUS } \\
\text { (normal dilution for } \\
\text { application of } 1.5 \text { to } \\
\text { 3mg/L) to be used in } \\
\text { the field. }\end{array}$ & $\begin{array}{l}\text { Main active } \\
\text { ingredient } \\
\text { organic } \\
\text { sulphonic acid } \\
\text { derivatives }\end{array}$ & $\begin{array}{l}\text { Stable but care needed } \\
\text { when handling, basic } \\
\text { PPE required. (see } \\
\text { above). }\end{array}$ \\
\hline
\end{tabular}

Retrieval Number: J09860641020/2020@BEIESP DOI:10.35940/ijmh.J0986.0641020

Journal Website: www.ijmh.org
Published By:

Blue Eyes Intelligence Engineering \& Sciences Publication

(c) Copyright: All rights reserved. and Hum

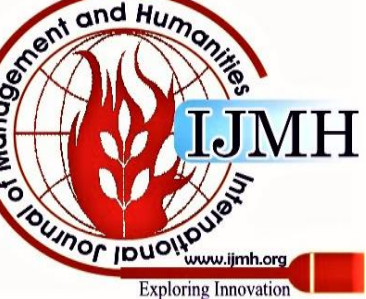




\begin{tabular}{|c|c|c|c|c|c|c|c|c|c|c|c|c|}
\hline 20 & Trisal & $\begin{array}{l}\text { Used for } \\
\text { stabilizing } \\
\text { granular base } \\
\text { materials }\end{array}$ & Salts & $\begin{array}{l}\text { Blending into road base } \\
\text { provides stabilization } \\
\text { similar to chlorides but } \\
\text { with no cure time required. }\end{array}$ & $\begin{array}{l}\text { No Data } \\
\text { Available }\end{array}$ & $\begin{array}{c}\text { No Data } \\
\text { Available }\end{array}$ & Soluble & No, inert & $\begin{array}{l}\text { No Data } \\
\text { Available }\end{array}$ & $\begin{array}{l}\text { May be harmful to } \\
\text { freshwater aquatic } \\
\text { species and to plants } \\
\text { not saline tolerant. }\end{array}$ & $\begin{array}{l}\text { Typically, } \\
\mathrm{MgCl}_{2} \text { in } \\
\text { aqueous } \\
\text { solution }\end{array}$ & Nothing specific \\
\hline
\end{tabular}




\section{ACKNOWLEDGMENTS}

I wish to acknowledge the contribution of my SLR colleagues in Namibia and the UK and Colin Christian \& Associates, to the original report on which this paper is based and to the Roads Authority of Namibia for funding the research.

\section{REFERENCES}

1. http://www.environmentguide.org.nz/eez/activity-status/sensitiveenvironments/

2. https://austroads.com.au/publications/pavement/agpt04l).

3....http://www.unece.org/fileadmin/DAM/trans/danger/publi/ghs/ghs_rev0 4/English/04e_part4.pdf

4. http://www.ilo.org/legacy/english/protection/safework/ghs/ghsfinal/ghs c14.pdf

5. Roald, S., Acute Toxicity of Lignosulfonates on Rainbow Trout, Bul. Envir. Contam. Toxicol. 17 No. 6, 702, (1977).

6. Enviro Technical Information for Problem Spills - Calcium Chloride. Environment Canada - Environmental Protection Service, May 1984.

7. Jones, J., Fish and River Pollution. Butterworths, Washington (1964) p 122.

8. Woodrow JE, Seiber JN, Miller GC. (2008 Apr 23;). "Acrylamide Release Resulting from Sunlight Irradiation of Aqueous Polyacrylamide/Iron Mixtures". Journal of Agricultural and Food Chemistry 56 (8): 2773-2779. doi:10.1021/jf703677v.

9. Ahn JS, Castle L. (5 November 2003). "Tests for the Depolymerization of Polyacrylamides as a Potential Source of Acrylamide in Heated Foods". Journal of Agricultural and Food Chemistry 51 (23). doi:10.1021/jf0302308

10. Smith EA, Prues SL, Oehme FW. (June 1997). "Environmental degradation of polyacrylamides. II. Effects of environmental (outdoor) exposure.". Ecotoxicology and Environmental Safety 37 (1): 76-91. doi:10.1006/eesa.1997.1527

11. Kay-Shoemake JL, Watwood ME, Lentz RD, Sojka RE. (August 1998). "Polyacrylamide as an organic nitrogen source for soil microorganisms with potential effects on inorganic soil nitrogen in agricultural soil". Soil Biology and Biochemistry 30 (8/9): 1045-1052. doi:10.1016/S0038-0717(97)00250-2

12. Gao JP, Lin T, Wang W, Yu JG, Yuan SJ, Wang SM. (1999). "Accelerated chemical degradation of polyacrylamide". Macromolecular Symposia 144: 179-185. ISSN 1022-1360

13. Ver Vers LM. (December 1999). "Determination of acrylamide monomer in polyacrylamide degradation studies by high-performance liquid chromatography". Journal of Chromatographic Science 37 (12): 486-494. http://www.j-chrom-sci.com/abstracts/1999/december/486ver.htm.

14. Environmental Effects of Applying Lignosulphonate to Roads, Adams J, Daishowa Chemicals Inc, 1988

15. http://www.transportlinks.org/transport_links/filearea/documentstore/115_Evaluation\%20of \%20SPPs.pdf

\section{AUTHORS PROFILE}

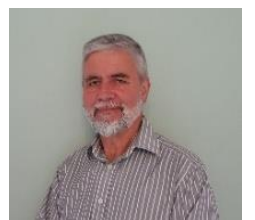

Eur Dr Peter J McKendry, BEng, PhD, CEng, CEnv, ACIBSE, MIMMM, CWM. Peter has over 40 years industrial and consultancy experience and has been in senior management roles in both industry and in consultancy. He worked for Blue Circle Industries for 14 years in cement and brick manufacture and the use of waste as fuels. As a Process Design Engineer Peter was involved in the design, construction and commissioning of process plants using wastes as fuels, including processed MSW, tyres, straw and landfill gas. He was the Process Engineer for the design, construction and commissioning of the world's largest, multi-use, landfill gas facility, Stone LFG Plant, Kent, UK. He has 28 years consultancy experience in the process design and specification of energy from waste projects, both thermal and biological, technical due diligence of projects for funders, energy efficiency surveys, preparation of contract documentation, permit applications, EIA and audit due diligence projects for both UK and international clients. Peter is a Chartered Engineer, Chartered Environmentalist, former Carbon Trust consultant, former
Lecturer on Uni. Bristol MSc course and mentor on Institute of Energy TEMOL course. 